\title{
LABOR MARKET DEVELOPMENTS DURING ECONOMIC TRANSITION*
}

\author{
Jan Rutkowski
}

World Bank Policy Research Working Paper 3894, April 2006

The Policy Research Working Paper Series disseminates the findings of work in progress to encourage the exchange of ideas about development issues. An objective of the series is to get the findings out quickly, even if the presentations are less than fully polished. The papers carry the names of the authors and should be cited accordingly. The findings, interpretations, and conclusions expressed in this paper are entirely those of the authors. They do not necessarily represent the view of the World Bank, its Executive Directors, or the countries they represent. Policy Research Working Papers are available online at http://econ.worldbank.org.

*This paper was prepared as a background paper for the 2005 ECA Labor Market Study. I would like to thank Mamta Murthi for helpful comments, and Barbara Ziolkowska for preparing the paper for publication. 


\section{INTRODUCTION}

The purpose of this paper is to identify key labor market trends and patterns which have emerged during the economic transition in Europe and Central Asia (ECA). The paper argues that the scarcity of productive job opportunities and growing labor market segmentation are the two main labor market problems in ECA. ${ }^{1}$ In the European transition economies (ETE)the lack of jobs has led to persistent open unemployment. In the Commonwealth of Independent States (CIS) it has led to hidden unemployment (underemployment or low-productivity employment). Unemployment in the European transition economies is supported by the developed social safety net. In contrast, in the CIS for most workers unemployment is not an affordable option. They either stick to their old, unproductive jobs in unrestructured enterprises, or work in the informal sector, or resort to subsistence agriculture. Low-productivity employment in the CIS is a mirror image of unemployment in the European transition economies. Accordingly, the high employment-to-population ratios still prevailing in many CIS countries do not necessarily signify favorable labor market performance. Instead they often indicate delayed enterprise restructuring, the maintenance of unsustainable jobs in uncompetitive firms, and the existence of a large informal sector as an employer of last resort. Labor market segmentation in transition economies has been caused by a sharp increase in earnings differentials and an attendant increase in the incidence of low-paid jobs, by the polarization of regional labor market conditions, and finally by the growth of the informal sector offering casual, low-productivity jobs. Labor market segmentation and accompanying inequalities are more pronounced in the CIS than in the European transition economies.

The scope of this paper is limited to the review of key labor market developments during the transition. A more in depth analysis of labor market transition is provided in (Svejnar, 1999). Useful discussion of labor market outcomes during the transition is also provided in Boeri and Terrel (2002) and Riboud et al. (2002). Rashid and Rutkowski (2001) examine labor market outcomes at an earlier stage of the transition.

The paper consists of four sections. Section I looks at labor force (quantity) adjustment to various macroeconomic shocks that hit transition economies countries during the 1990s. Section II focuses on the characteristics of unemployment in ECA. Section III examines the wage (price) adjustment. Section IV summarizes key stylized fact on labor market transition..

\footnotetext{
1 The term "European transition economies" (ETE) refers to countries of Central and Eastern Europe (CEE) and Southern and Eastern Europe (SEE). The latter includes countries of the former Yugoslavia except Slovenia plus Albania. The Commonwealth of Independent States (CIS) is comprised of the countries of the FSU: Belarus, Russia and Ukraine (BRU), and the other CIS countries. The latter include so called CIS-7 and Kazakhstan (CIS-7 + K).
} 


\section{LABOR FORCE, EMPLOYMENT AND UNEMPLOYMENT}

\section{Large employment reductions in European transition economies and modest ones in the CIS}

One key feature of the labor market under the soviet-style socialism was high labor force participation and full employment. Unemployment was virtually nonexistent. Full employment was achieved through overstaffing made possible by the soft budget constraint. Overstaffing, also referred to as labor hoarding, meant that enterprises were employing more workers that was necessary to produce given output. This meant "unemployment on the job" and low labor productivity, which translated into low wages.

The situation was different in Yugoslavia, where enterprises were exposed to competition and faced harder budget constraint. In addition, labor managed firms - the salient feature of the Yugoslav system - did not have an incentive to maximize employment, but instead awarded workers, who formally owned the firm, higher wages.

Profound institutional and structural changes associated with the economic transition economic liberalization, privatization, hard budget constraint, and the emergence of product market competition - as well as the disintegration of existing economic ties led to a substantial drop in output. This was followed by both employment and wage adjustments, although the patterns of adjustment varied by sub-regions. Generally, in European transition economies the burden of adjustment fell on employment, while in the FSU countries the burden of adjustment fell on wages.

In European transition economies employment is presently 20 to 30 percent lower than before the transition. The job loses were heavily concentrated during the first phase of the transition (until the mid-1990s) and continued at a much slower pace afterwards. After all, since the late 1990s some countries (the Baltic states, Hungary, Slovenia) have seen net job creation and employment growth. Romania is an exception to this pattern, as employment started to decline there later than in other countries, indicating delayed restructuring.

As to the middle-income CIS, in Kazakhstan and Ukraine job losses were of similar magnitude as in the Central and East European (CEE) countries (some 30 percent), with job destruction accelerated in the second half of the 1990s, again pointing to delayed restructuring. In contrast, in Belarus and Russia, the drop in employment was much more modest, accounting for around 15 percent.

In the low-income CIS countries the fall in employment apparently has been much more modest than in other transition economies, although for many countries consistent time series on employment are lacking. For example, in Moldova employment declined by less than 10 percent during 1990-2002. In a few CIS-7 countries (Azerbaijan, Kyrgyz Republic, Uzbekistan) employment has started to increase in the late 1990s. 


\section{Box 1 Measurement of employment: household vs. firm based surveys}

The magnitude of measured employment decline in transition economies depends on the statistical source. It tends to be much larger if data come from firm based Employment surveys, and relatively smaller if data comes from the household based Labor Force Survey (LFS). The discrepancy stems from the fact that firm based surveys cover only registered, formal sector firms, while the LFS in principle provides data on all employed individuals. Thus, the difference in employment between those two sources is an approximate measure of informal sector employment, employment in small private firms, which often are under-represented in employer based-surveys, and self-employment. This difference also reflects the changing nature of jobs in ECA. There has been a partial shift from regular full-time jobs toward casual jobs, often in the informal sector, as well as a partial shift form wage and salary employment towards self-employment. The firm based employment surveys do not account for irregular jobs and overestimate the actual job loses, however they show quite accurately the decline in the number of traditional, regular jobs.

\section{Despite the substantial job loses the employment ratio is still relatively high}

The substantial job loses that have occurred during the transition are reflected in the lower degree of the utilization of labor resources. The employment ratio - which shows the percentage of the population of working age that is employed -is presently much lower than before the transition in virtually all transition economies. On average it dropped by close to 20 percentage points in CEE, around 15 percentage points in Belarus, Russia and Ukraine, and some 10 percentage points in other CIS (Figure 1). This means that 10 to 20 percent of the working age population which would have been employed under the old regime, is currently without work. Apparently, this is a large decline in the utilization of labor. However, despite this big decline, the employment ratio in most transition economies is still within the OECD range.

Figure 1 Transition has been associated with a substantial fall in the employment-topopulation ratio

Employment/Population Ratio, 2002

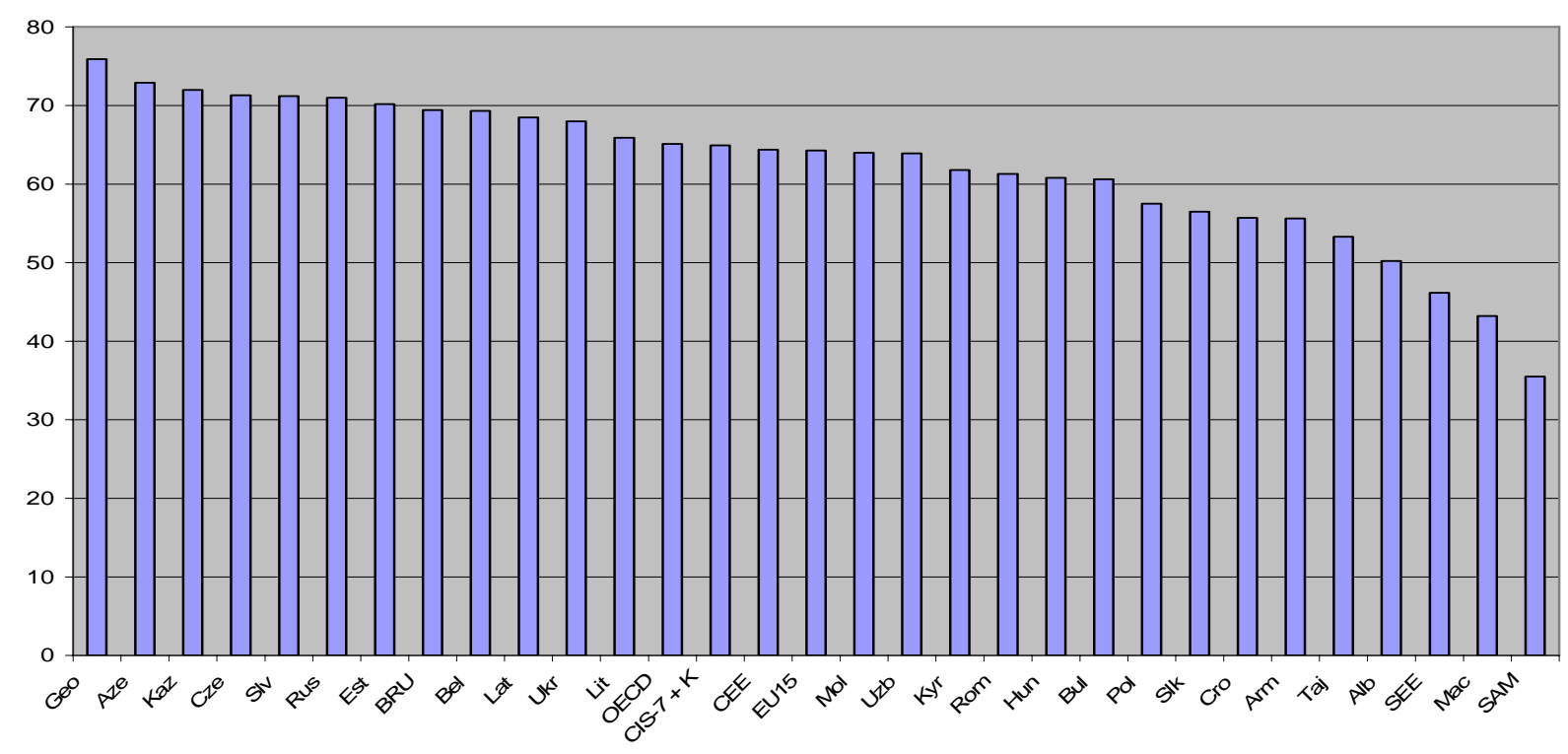

Source: UNICEF TRansMONEE database; OECD Employment Outlook, 2003 
The average employment ratio for CEE is presently about 64 percent, virtually the same as for the European Union (before the enlargement) and for the OECD. In the CIS it is even higher, above the OECD average. This somewhat surprising observation reflects the fact that under central planning the employment ratio tended to be at an unusually high level. The transition has been thus associated with a movement of employment rates towards a level characteristic of market economies. Such process is called a regression toward the mean. In many transition economies the current employment rates may be close to the equilibrium rates, which implies that there will be no return to the high employment rates prevailing before the transition.

Obviously, there is a substantial variation in employment ratios across countries. On the one hand, there are transition economies where the ratio is around 70 percent, which is high by international standards. These include the Czech Republic, Estonia, Lithuania in CEE, Belarus and Russia, and Azerbaijan and Kazakhstan among the other CIS (Figure 2).

\section{Figure 2 Employment rates vary among transition economies}

Change in the Employment Rate, 1989-2001

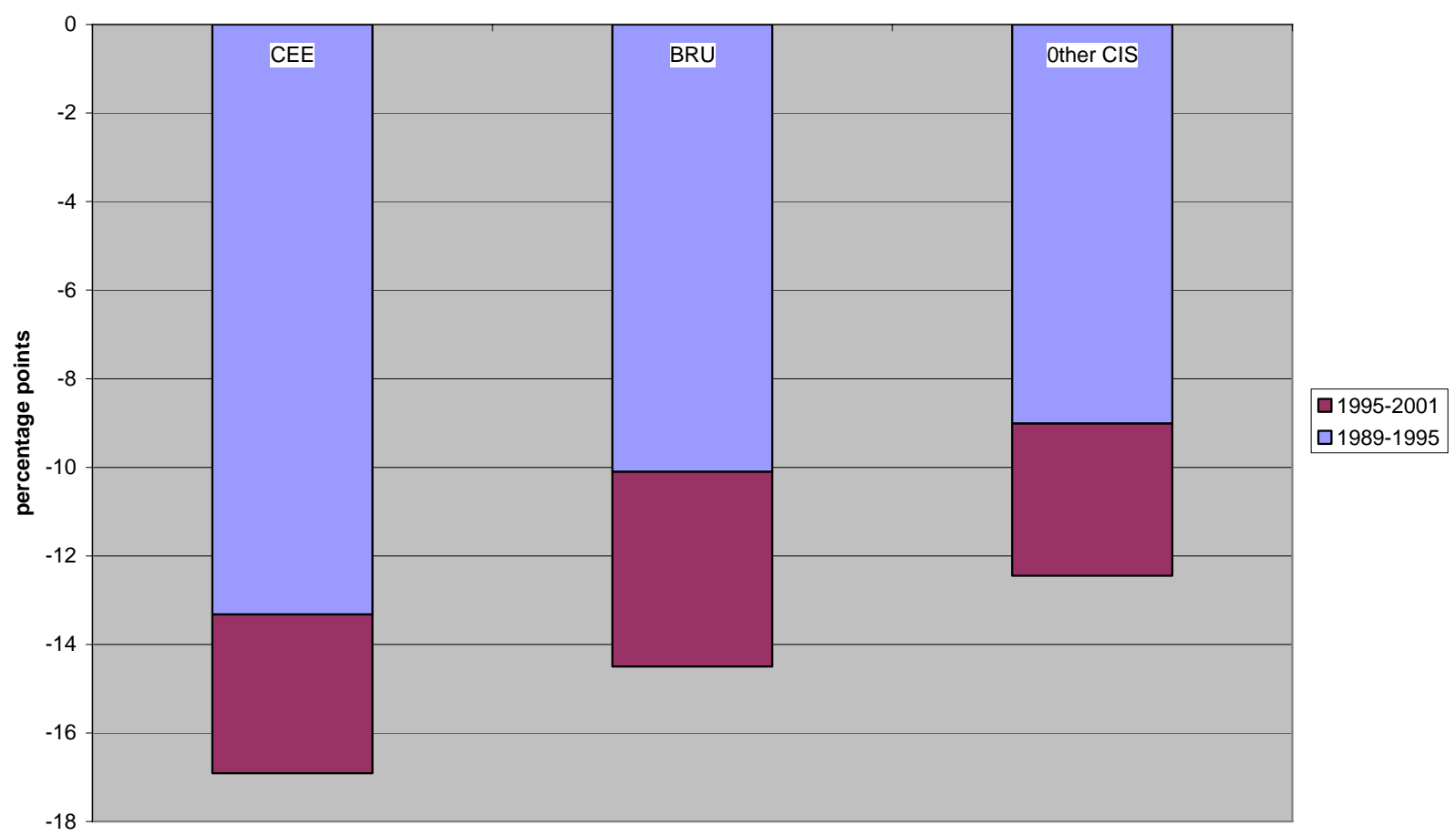

Source: UNICEF TransMONEE database; Bank staff calculations

On the other end of the spectrum are countries such as Bulgaria, Poland and Slovakia among the CEE countries, and Armenia and Tajikistan among the CIS, where the employment ratio is significantly below the OECD average.

\section{High employment rates in slowly restructuring countries may not be sustainable}

High employment rates may imply a successful transition (Estonia is probably a good example), but may also imply slow and delayed restructuring. In the latter case many existing jobs are of low productivity and probably are not viable in the longer-run. The symptoms indicating the existence of low-productivity and non-viable jobs include high prevalence of wage 
arrears, forced unpaid leave, short working hours. These jobs can exist only as long as enterprises are not subject to competition and receive direct or indirect subsidies (e.g. tax arrears, non-payment of utility bills). Such non-viable jobs still exist largely in the CIS countries, including Belarus, Moldova, Russia and Ukraine, where enterprise restructuring has proceeded at a slower pace (See Box 2)

\section{Box 2 High employment but many of the jobs are of low productivity and unviable}

Moldova is an example of a country with a relatively high employment and a low unemployment rates where a large proportion of jobs is of low productivity and thus probably unsustainable. As much as 20 percent of privatized firms reported overstaffing in 2001. Moreover, one of every 10 workers was on a forced unpaid leave and the average duration of such leave was three months. Many Moldovan firms close for a part of the year. As a result of the low level of activity in poorly performing firms the actual hours of work are very low. An average workers in Moldova works only 28 hours per week, while his Polish, say, counterpart works 42 hours. Similar problems, although to a lesser and decreasing degree occur in Russia (World Bank, 2003).

Source: Rutkowski (2004)

\section{Emergence of unemployment and decline in labor force participation}

The dramatic decrease in the number of available jobs caused by the shocks associated with economic transition, especially at its early stage, gave rise to unemployment and the fall in labor force participation. The unemployed are, by definition, those workers who lack jobs and are actively looking for new ones. Persons out of the labor force (economically inactive) comprise of two categories. First, the discouraged workers, that is able bodied people of working age who would like to work, but who gave up job search as their efforts proved futile and they ceased to believe that they can find a job. Second, persons who for various reasons are not interested in having a job, for example students enrolled in full time education, homemakers, persons with disability, or older persons. The dynamics of unemployment and the labor force hinges on labor market conditions. Unemployment tends to increase as labor market conditions deteriorate. However, it may temporarily increase in response to the increase in the availability of job opportunities as workers who had been inactive enter the labor market and start looking for jobs. Labor force participation as a rule falls when labor market conditions worsen. Some workers become discouraged, and cease looking for jobs (thus, rather than being classified as unemployed they are classified as inactive). Younger people may chose to stay longer in education to delay the entering the labor market. Some workers may take advantage of benefits offered by the welfare state: social assistance, disability pensions, or early retirement. Older workers chose retirement and do not try to supplement their pensions with income from work.

In the transition economies all these effects have occurred in response to the fall in aggregate and, consequently labor, demand. Labor force participation rates fell and unemployment rose across the board. However, in various countries these effects have occurred in different proportions. In some countries the loss of jobs has translated largely into an increase in unemployment. In others, it has mainly led to a fall in labor force participation rates. Thus, labor force patterns differ across ECA countries (Table 1). For example, in the late 1990s the employment ratio - and thus roughly the number of available jobs - in Hungary and Poland was virtually the same. However, unemployment in Poland was high (well over 15 percent), while in Hungary it was relatively low (below 10 percent). Thus, Hungary and Poland exhibited different 
pattern of adjustment to the fall in demand and job losses: in Hungary the reaction was mainly labor force withdrawal, whereas in Poland it was mainly active search for new jobs. These differential responses can be accounted for by differences in labor market institutions (e.g. benefit systems).

Table 1 Employment, unemployment and labor force participation, 2001

\begin{tabular}{|c|c|c|c|}
\hline & $\begin{array}{c}\text { Employment } \\
\text { Rate }\end{array}$ & $\begin{array}{l}\text { Unemployment } \\
\text { rate }\end{array}$ & $\begin{array}{l}\text { Labor force } \\
\text { participation } \\
\text { rate }\end{array}$ \\
\hline CEE & 59.3 & 11.0 & 67.1 \\
\hline Bulgaria & 50.6 & 18.1 & 61.9 \\
\hline Czech Republic & 65.5 & 7.3 & 70.7 \\
\hline Estonia & 62.0 & 9.1 & 69.3 \\
\hline Hungary & 56.6 & 5.6 & 60.1 \\
\hline Latvia & 60.4 & 12.8 & 68.8 \\
\hline Lithuania & 59.9 & 13.1 & 69.6 \\
\hline Poland & 51.5 & 19.9 & 64.6 \\
\hline Romania & 57.6 & 7.0 & 63.4 \\
\hline Slovakia & 56.8 & 18.6 & 69.9 \\
\hline Slovenia & 63.4 & 6.0 & 67.8 \\
\hline SEE & 45.7 & 19.1 & 56.8 \\
\hline Bosnia and Herzegovina & 40.1 & 16.4 & 48.0 \\
\hline Croatia & 53.7 & 14.4 & 62.9 \\
\hline Macedonia, FYR & 40.4 & 31.9 & 59.8 \\
\hline Serbia and Montenegro b) & 48.5 & 13.8 & 56.3 \\
\hline BRU & 67.9 & 9.6 & 72.6 \\
\hline Belarus & - & - & - \\
\hline Russia a) & 75.8 & 8.0 & 82.5 \\
\hline Ukraine & 60.0 & 11.1 & 62.7 \\
\hline Other CIS & 56.9 & 11.0 & 63.7 \\
\hline Armenia & - & - & - \\
\hline Azerbaijan & - & - & - \\
\hline Georgia b) & 56.8 & 12.3 & 65 \\
\hline Kazakhstan c) & 63.6 & 9.3 & 70.1 \\
\hline Kyrgyzstan & - & 12.5 & - \\
\hline Moldova d) & 50.4 & 9.8 & 56.0 \\
\hline Tajikistan & - & - & - \\
\hline Uzbekistan & - & - & - \\
\hline \multicolumn{4}{|l|}{ Memorandum } \\
\hline OECD & 65.1 & 6.9 & 69.9 \\
\hline EU15 & 64.3 & 7.7 & 69.7 \\
\hline
\end{tabular}

- Data not available

Note: Labor Force Survey data

Definitions:

Working-age population: 15-64

Labor force $=$ employed plus unemployed (aged 15+)

Labor force participation rate = labor force 15-64 as a percentage of working age population

Employment rate $=$ employed $15-64$ as a percentage of working age population

Unemployment rate $=$ unemployed as a percentage of the labor force 
a) Working age population: 20-59

b) Working age populations: $15+$

c) Working age population: 15-74

d) 1st quarter of 2003

Source:

CEE countries and EU: Eurostat (Employment in Europe 2003)

Bosnia and Herzegovina: World Bank (2002b)

Croatia: Central Bureau of Statistics, Labour Force Survey 2002 (second half), Bank staff calculations.

Serbia and Montenegro: Republic of Serbia, Republican Statistical Office, Labor Force Survey 2002 (October), Bank staff calculations

Georgia, Kazakhstan and Kyrgyzstan: ILO LABORSTA Labour Statistics Database; Bank staff calculations.

Russia: Goskomstat; Bank staff calculations.

Moldova: Department of Statistics and Sociology of the Republic of Moldova; Bank staff calculations

Different labor force responses to the accelerated job destruction occurring in the wake of economic restructuring have given rise to different labor market patterns, which are summarized in Table 2.

Table 2 Patterns of labor force adjustments

\begin{tabular}{|c|c|c|}
\hline \multirow{2}{*}{ Labor force participation } & \multicolumn{2}{|c|}{ Unemployment } \\
\hline & High & Low \\
\hline \multirow[b]{2}{*}{ High } & $\begin{array}{l}\text { Limited job opportunities. But } \\
\text { workers look for jobs. }\end{array}$ & $\begin{array}{l}\text { High employment. But are the } \\
\text { jobs sustainable? }\end{array}$ \\
\hline & $\begin{array}{l}\text { Georgia, Lithuania (late } \\
\text { 1990s), Poland (late 1990s), } \\
\text { Serbia, Slovakia, Ukraine }\end{array}$ & $\begin{array}{l}\text { Czech R., Estonia, Lithuania } \\
\text { (2000s), Moldova, Romania, } \\
\text { Russia, Slovenia }\end{array}$ \\
\hline \multirow{2}{*}{ Low } & $\begin{array}{l}\text { Scarcity of jobs. Some workers } \\
\text { get discouraged while others } \\
\text { continue searching for jobs. }\end{array}$ & $\begin{array}{l}\text { Limited job opportunities. } \\
\text { Most workers cease looking } \\
\text { for jobs. }\end{array}$ \\
\hline & $\begin{array}{l}\text { Bulgaria, BiH, Croatia, Latvia, } \\
\text { Macedonia, Poland (early } \\
\text { 2000s) }\end{array}$ & Hungary \\
\hline
\end{tabular}

The four basic patterns of adjustment are as follows.

High employment. The category combining high labor force participation rate and low unemployment rate implies a high employment-to-population ration, and thus is apparently the most desirable one. However, it comprises two distinctly different sub categories: countries such as Estonia or Slovenia, where high employment is a consequence of successful transition, and countries, such as Moldova or Romania, where high employment is associated with slow restructuring and a high share of low productivity jobs (e.g. in subsistence agriculture, or in nonprofitable enterprises). To some extent, the delayed restructuring can be tracked back to the nature of the privatization process in this countries (mass privatization schemes with dispersed ownership structures and thus weaker governance).

Limited job opportunities: in search of jobs. This category comprises countries such as Georgia or Slovakia, where labor force participation rates are high, but so is unemployment. This combination suggests that unemployed workers still see employment opportunities and thus actively search for jobs. Relatively few workers are discouraged and gave up job search. As a 
result, employment level is still relatively high. In a way, this labor market state is a transient one. It can evolve into a depressed labor market, as it has happened in Poland in early 2000s, or into vibrant labor market as it has happened in Lithuania at around the same time.

Limited job opportunities: discouragement. Hungary is an example of a country where in the face of limited job opportunities a large fraction of jobless workers withdraws from the labor force. Unemployment is thus low, but so is the labor force participation rate (which may be possible thanks to the availability of non-employment benefits). As a result, low unemployment coincides with relatively low employment. The employment effect is similar to that in countries where both the labor force participation and unemployment are higher (the previous group).

Scarcity of jobs: unemployment and discouragement. This combination of high unemployment and low labor force participation rates, prevailing in countries such as Bulgaria and Croatia, signifies a depressed labor market, with the resulting low employment level. High unemployment in this case is likely to reflect the fact that many jobless workers (e.g. primary earners, the poor) cannot afford to be out of the labor force and are compelled to actively search for work.

To sum up, labor force adjustment has taken various forms during economic transition. In some countries, changes in labor demand led mainly to changes in unemployment, in others mainly to changes in labor force participation. Moreover, labor market adjustment during the transition has been a dynamic process, with changes in labor market conditions inducing movements between unemployment and economic inactivity (Boeri, 1995).

\section{Disproportionately low male employment rates}

The male employment rate is significantly higher than the female employment rate in all transition economies. ${ }^{2}$ This is due to the difference in the labor force participation rate, which is much lower for women, rather than the unemployment rate which tends to be similar for men and women (Figure 3).

\section{Figure 3 Labor force indicators by gender, 2002}

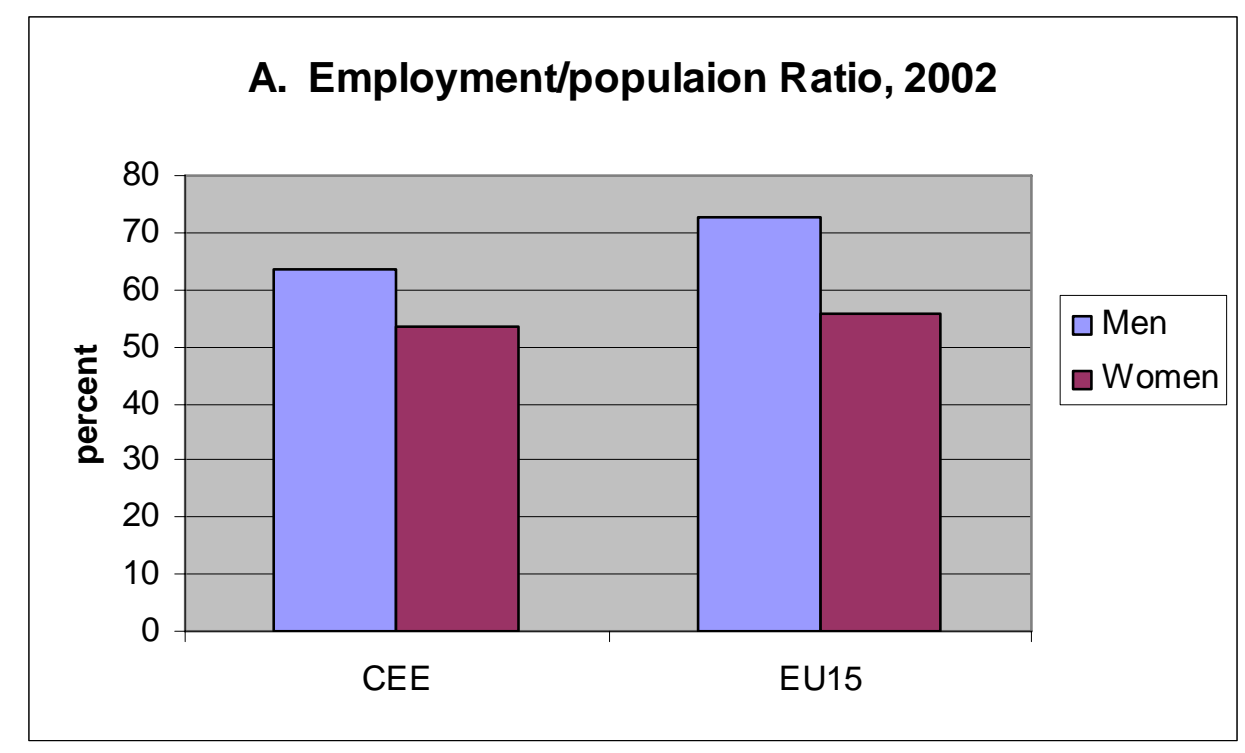

2 This statement is based on data for CEE countries and Russia. However, it is highly unlikely that the common pattern of higher male than female employment rate does not apply to other ECA countries. 

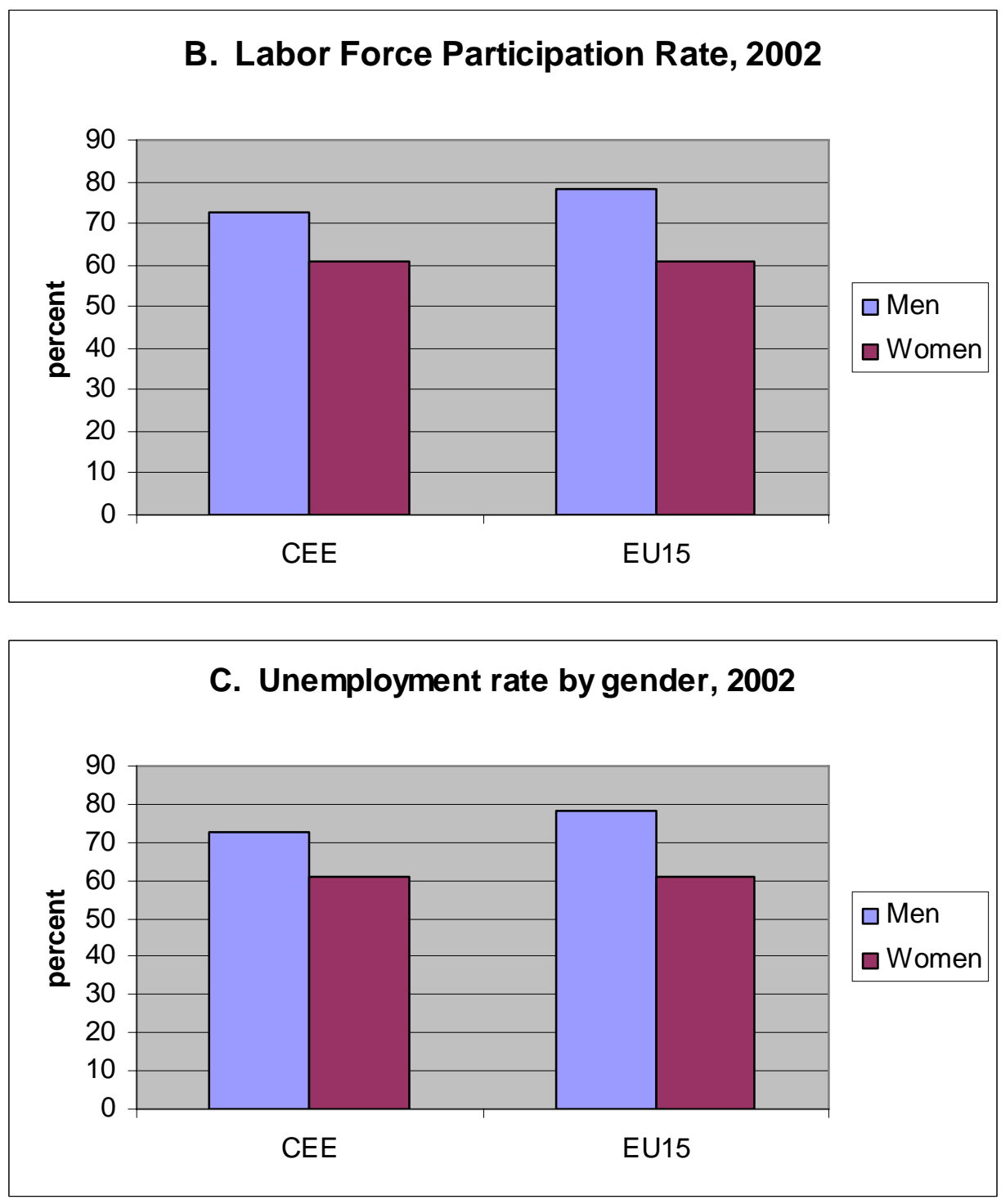

This is not surprising, however, as the female labor force participation rate, and correspondingly the employment rate, is lower than that of men in virtually all societies, and the transition economies are no exception to this regularity. For example in the EU15, the gap between the male and female labor force participation rate is 17 percentage points, compared with 12 percentage points in CEE. So, the gap between the male and female labor force participation rate is significantly smaller in CEE countries than in the EU15. Given that the female labor force participation rate in CEE is the same as in the EU15 (on average 61 percent), and the employment rates are pretty similar, there is no sign of the underutilization of female labor in CEE. The picture is different, however, in the low-income CIS countries, where female labor force participation rate has been traditionally lower.

Where CEE countries differ from the EU15 countries is not female but male employment. It is male labor resources that are underutilized. In CEE both the male labor force participation rate and the employment rate are much lower than in EU15, which is in stark contrast with the female rates. To illustrate, there is a 6 percentage points gap in the male labor force participation rate between the EU15 and CEE (no such gap in the case of the female labor force participation rate). Given that male unemployment is much higher in CEE than in EU, this translates into an even bigger difference in the male employment rate: 64 percent in CEE compared with 73 
percent in EU15. Thus, if one uses the EU15 as a benchmark, men are underemployed in CEE, while women are not.

What explains these particularly low male employment rates? On possible explanations is that the restructuring process has been biased against manual, less skilled labor and this has put men at disadvantage. The industries that have been declining, especially the heavy industry, were employing predominantly male labor. In contrast, the expanding service sector relies to a much greater extent on female labor. Moreover, the restructuring is associated with the increase in the relative demand for higher, mainly non-manual, skills which benefits women more, as in many transition economies women tend to be better educated than men. In other words, there is indication that during the transition the demand for male labor, which tends to be manual and less skilled - has been hurt more than that for the female labor, which tends to be non-manual and more skilled.

In addition, one should bear in mind that the female labor force participation rates were very high by international standards in most socialist countries, and accordingly the gender gap in labor force participation was relatively small. The transition shock lowered both male and female employment rates, but while it has brought female employment rates to the EU level, it brought the male rates well below the EU level. This and other aspects of the gender labor market differences in transition economies are explored in more detail in Paci (2002).

\section{The changing nature of employment}

In socialist economies workers were used to having regular, full time wage and salary employment. Jobs were secure (permanent employment contracts were the norm; dismissals were possible only for major misdemeanor, and thus very rare) and employment was providing a range of fringe benefits. This has changed dramatically during the course of transition. Job security was largely lost as attested by high job separation rates prevailing in most transition economies. In addition, employers have increasingly turned to fixed-term or temporary employment contracts to facilitate workforce adjustment. Benefits were cut-off as subsidies were removed and enterprises had to become competitive in order to stay in business. The proportion of regular secure jobs has gone down, while that of casual, precarious jobs has gone up. This changing nature of job has been associated with the growth of the informal sector, which by definition provides less protected jobs with fewer benefits. On top of this, many workers who lost (or were not able to find) wage and salary employment turned into selfemployment, which largely is a coping strategy as opposed to a means of securing higher earnings (Verme, 2004). Informality and self-employment are often associated with agricultural activities, especially in countries with a high share of agriculture in employment (the CIS, Poland, Romania, FYR Macedonia). Agriculture tended to act as a shock-absorber for some workers released from manufacturing, however underemployment in agriculture is substantial, and accordingly productivity is low. Subsistence farming is common.

These trends are difficult to document with hard data. We will focus here on three aspects of the changing nature of employment in ECA: informal sector employment, selfemployment, and irregular jobs. In the next section we will show the evolution of the industrial structure, including changes in the size of the agricultural sector. 


\section{Large informal sector}

The size of the informal sector (measured by its share in total employment) varies visibly across sub-regions within ECA, as well as across countries. ${ }^{3}$ Still, the informal sector is an important source of jobs in all sub-regions and in virtually all countries (Figure 4). For comparison, its role in ECA is much greater than in OECD countries. In CEE, for example, the informal sector contributes to GDP nearly twice as much as in OECD countries (respectively 29 and 17 percent on average in 2000).

\section{Figure 4 Informal sector employment plays an important part in all transition economies, but especially in less developed ones}

Employment in the Informal Sector, 1998/1999

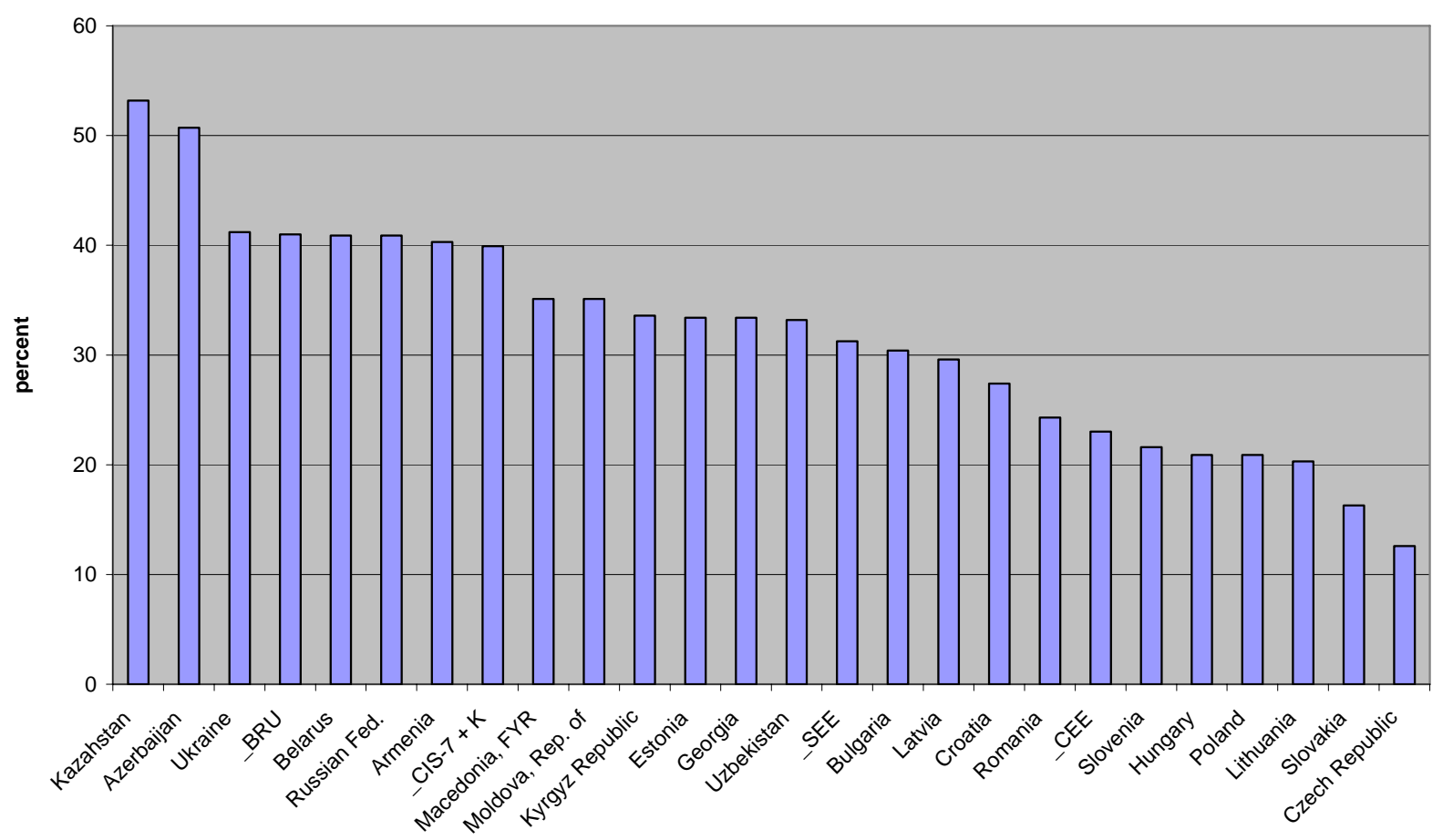

Source: Schneidr (2002), Scheider and Klingmair (2004)

The size of the informal sector seems to be smaller - although not negligible - in the more advanced CEE countries, and is particularly large in low-income economies of the CIS. In $\mathrm{CEE}$ one in five to one in four workers work in the informal sector. In Southeastern Europe (SEE) the proportion goes up to one in three. In the CIS every third to every second worker has an informal sector job.

The cross country variation is substantial. On the one end of the spectrum are the Czech Republic and Slovakia, where the informal sector accounts for around 15 percent of employment, which is close to the OECD average. The percentage is about twice as high in Bulgaria, Estonia and Latvia and reaches 40 percent in Belarus, Russia and Ukraine. At the

\footnotetext{
3 The commonly used definition of the informal sector is: "all currently unregistered economic activities which contribute to the officially calculated (or observed) Gross National Product" (Schneider, 2002). Specifically, the "shadow labor market includes all cases, where the employees or the employers, or both occupy a "shadow economy" position (ibidem). Unfortunately, Schneider (2002) does not provide details on how the estimates of the "shadow economy labor force" (presented below) were obtained.
} 
other end of the spectrum are Azerbaijan and Kazakhstan, where the informal sector accounts for half of the economy.

There are important differences in informal sector characteristics between the European and the CIS transition economies. Apart from the differences in size, there are also differences in the underlying causes and functions of the informal sector activity (see Box 3).

\section{Box 3 The meaning of informality: European vs. CIS transition economies}

The informal sector has grown across all transition economies. However, the key characteristics of the sector differ between the European and the CIS transition economies at least in three main respects. First, the size of the informal sector in European economies is smaller than in CIS economies. Second, in the European transition economies workers and firms move to the informal sector mainly to evade high taxes and avoid strict regulations. In contrast, in the CIS economies the informal sector is largely an employer of last resort providing subsistence income. Small firms prefer to stay in the informal sector to avoid corruption and extortion. Third, in the European transition economies informal sector activity is often a preferred alternative to work in the formals sector, or complements work in the formal sector (e.g. moonlighting). In the CIS economies, in contrast, informal sector activity is usually a necessity reflecting lack of employment opportunities in the formal sector and is a primary source of income. In addition, the characteristics of informal sector employment differ between both groups of countries. For example, in the CIS economies most informal sector jobs are in agriculture while in the European transition economies they are frequently located in the services sector, including informal employment in registered firms. Table A summarizes these differences.

Table A Informal sector in European and CIS transition economies. Stylized facts

\begin{tabular}{|l|l|l|}
\hline $\begin{array}{l}\text { Informal sector } \\
\text { characteristics }\end{array}$ & $\begin{array}{l}\text { European transition } \\
\text { economies }\end{array}$ & CIS transition economies \\
\hline Size & Modest & Large \\
\hline Causes & $\begin{array}{l}\text { tax avoidance and evasion; } \\
\text { stringent regulations in } \\
\text { regulations }\end{array}$ & $\begin{array}{l}\text { lack of alternative job } \\
\text { opportunities; } \\
\text { corruption and extortion in the } \\
\text { formal sector }\end{array}$ \\
\hline Functions & $\begin{array}{l}\text { preferred alternative to formal } \\
\text { sector employment; source of } \\
\text { secondary income }\end{array}$ & $\begin{array}{l}\text { employer of last resort; } \\
\text { primary source of subsistence } \\
\text { income }\end{array}$ \\
\hline Employment status & $\begin{array}{l}\text { self-employment; in } \\
\text { dependent employment in } \\
\text { unregistered interprises; } \\
\text { informal employment in } \\
\text { registered enterprises; }\end{array}$ & $\begin{array}{l}\text { elf-employment; } \\
\text { enterprises }\end{array}$ \\
\hline Nature of jobs & $\begin{array}{l}\text { legular jobs, part-time jobs, } \\
\text { temporary jobs; second jobs }\end{array}$ & $\begin{array}{l}\text { agricultural, casual, occasional } \\
\text { and seasonal jobs }\end{array}$ \\
\hline
\end{tabular}

Obviously, the table presents highly stylized fact and in reality the differences are not so sharp. The informal sector in European transition economies shares some features of that in the CIS ones, and vice versa. The above characteristics thus highlights the dominant distinctive features while it disregards similarities. 
Self-employment plays the most important part in the low-income CIS, where on average it accounts for 50 percent of total employment. The share of self-employment is much lower in the middle-income CIS (17 percent), and in CEE (20 percent). By way of comparison, in EU15 countries, self-employment accounts for about 15 percent of total employment.

There is substantial degree of variation in the share of self-employment within regions. It is particularly pronounced in CEE (Figure 5). On the one extreme are countries such as Estonia and Slovakia, where self-employment plays a minor part, accounting for less than 10 percent of total employment. On the other extreme there are countries such as Romania, Lithuania or Poland, where self-employment plays a major role, accounting for some 30 to 40 percent of total employment. In interpreting these figures one should notice that self-employment is often agricultural employment by a different name. That is, in countries where agriculture plays an important part self-employment as a share of total employment tends to be high as farmers are as a rule counted as the self-employed. This is obviously not to deny, that self-employment plays an important part outside agriculture.

In addition, cross-country and time comparisons may be obscured by the fact that in some cases there is little difference between dependent wage employment and self-employment. For example in Bulgaria and Poland some health care sector employees were turned into independence, self-employed contractors. This obviously inflated the number of the selfemployed, although there was no corresponding change in the nature of jobs. These measurement problems notwithstanding, there is little doubt that self-employment gained in prominence in transition economies and often accounts for a considerable fraction of jobs.

\section{Figure 5 Self-employment plays a critical role in CIS-7 and a negligible one in BRU whereas CEE countries are between these two extremes}

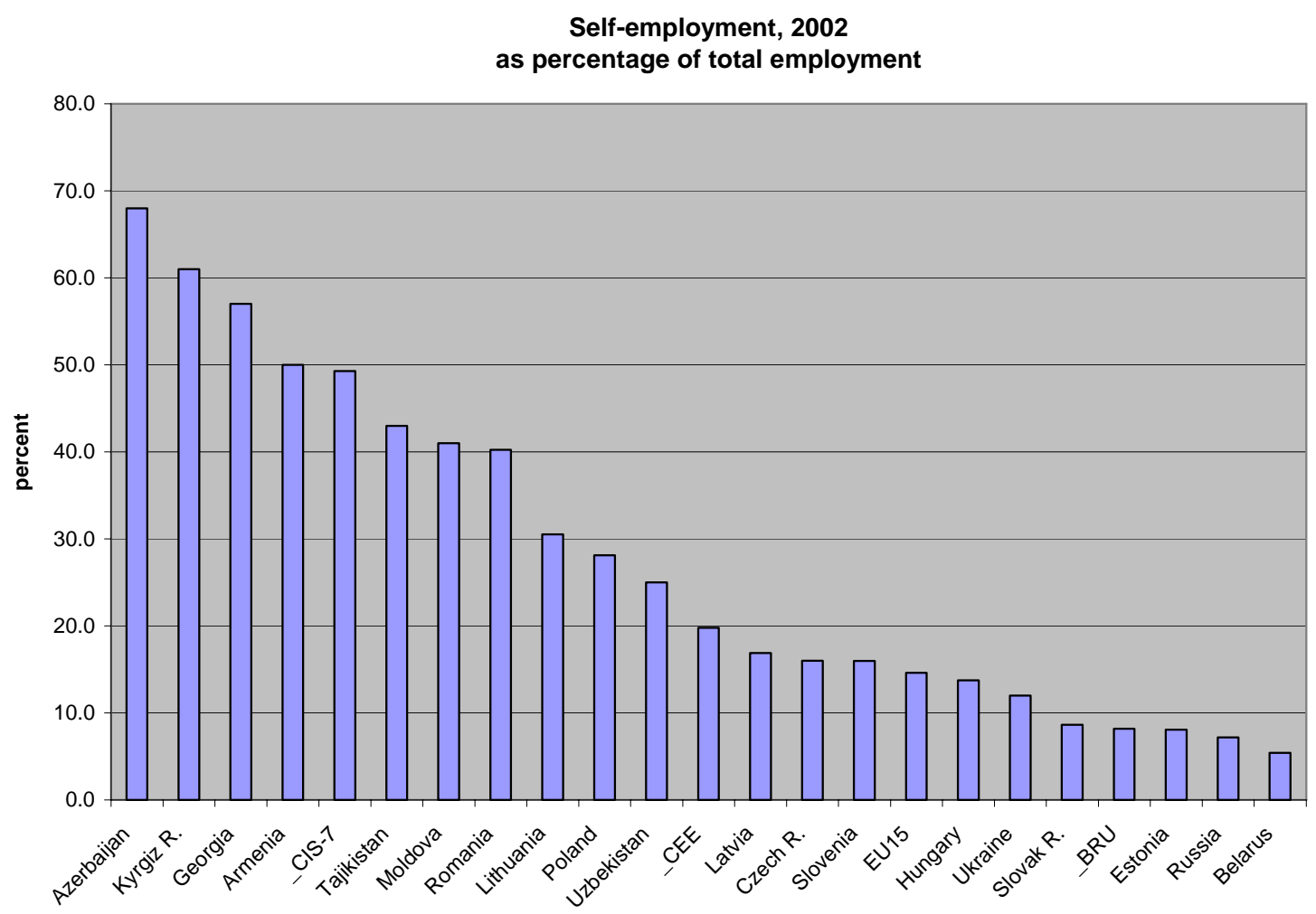

Source: Eurostat, CIS-stat (2003) 
What are the reasons behind this development? On the one hand people are pushed into self-employment by lack of work opportunities. In such a case self-employment is the only available means of earning subsistence income. Also sometimes employers force workers into self-employment as a means lowering hiring and firing costs, as in the above example of health care sector reform in Bulgaria and Poland. In this case self-employment is a forced choice reflecting the lack of a gainful alternative. On the other hand people can be pulled into selfemployment if the expected benefits, mainly earnings, exceed than those of wage employment. Self-employment in this case is a voluntary welfare-maximizing choice among different alternatives. In such a case self-employment often becomes a springboard for firm creation.

In reality self-employed workers comprise of both categories: aspiring entrepreneurs and subsistence workers for whom unemployment is not a viable alternative (Box 4). However, there is some evidence that in ECA the push factors tend to prevail, and the majority of self-employed resort to self-employment to avoid unemployment and earn subsistence income (Earle and Sakova, 2000; Verme, 2004). The recourse to subsistence agriculture (as it has happened in Poland, Romania, FYR Macedonia and in the most of CIS) is the point in case. Thus, the evidence does not support the optimistic view that the rise in self-employment reflects the development of entrepreneurship and new business opportunities. To a large extent it reflects difficult labor market conditions and lack of work opportunities.

\section{Box 4 Self-employment: a springboard for firm creation, or a coping strategy?}

Is the growth in self-employment observed in transition economies a positive phenomenon? On the one hand it is an indication of a developing entrepreneurial spirit, and a springboard to starting a small business. Self employment can be a source of an "entrepreneurship premium" and as such offer better than normal earning opportunities.

On the other hand, the growth in self-employment may be a symptom of a depressed labor market, where firms create few jobs, and employment opportunities are scarce. It can be associated with low value-added activates, which barely provide substance income. So, the assessment depends on the distribution of productivity and earnings associated with self-employment jobs (relative to that of dependent employment). At the same time, self-employment needs to be assessed against the counterfactual, which is either lower earnings or no earnings whatsoever. From such a perspective, selfemployment is unambiguously a welfare enhancing economic activity.

For example, in Albania or in Georgia the self-employed account for a large proportion of the poor, and thus self-employment is a copying strategy, a means of earning subsistence income. In contrast, in more developed countries, such as Estonia or Hungary, the incidence of poverty among the selfemployed is negligible. In this context self employment is likely to be a gainful entrepreneurial activity (World Bank, 2000).

\section{Rising incidence of irregular jobs?}

The nature of dependent wage employment has been also changing. Before the transition employment meant full time permanent labor contract. At present, fixed-term and part-time jobs account for a significant part of total formal sector employment in transition economies. On average, fixed term jobs share in total employment exceeds 7 percent, and that of part-time jobs is another 7 percent (Table 3). In both cases, there is visible cross-country variation. The incidence of fixed-term contracts ranges from less than 3 percent in Estonia to over 15 percent in Poland. For comparison, the EU15 average is 13 percent. As to part-time jobs, their incidence 
ranges from less than 3 percent in Bulgaria to over 10 percent in Latvia, Poland and Romania. It is noteworthy, that the incidence of part-time jobs in CEE is substantially below the EU15 average of 18 percent.

Table 3 Flexible jobs in CEE are less prevalent than in EU

\begin{tabular}{lrrr}
\hline & $\begin{array}{c}\text { Self- } \\
\text { employed }\end{array}$ & $\begin{array}{c}\text { Fixed } \\
\text { term } \\
\text { contracts }\end{array}$ & $\begin{array}{c}\text { Part-time } \\
\text { employment }\end{array}$ \\
\hline Bulgaria & - & 5.3 & 2.5 \\
Czech R. & 16.0 & 8.1 & 4.9 \\
Estonia & 8.1 & 2.7 & 7.7 \\
Hungary & 13.7 & 7.3 & 3.6 \\
Latvia a) & 16.9 & 6.7 & 11.3 \\
Lithuania b) & 30.5 & 6.3 & 9.7 \\
Poland & 28.1 & 15.4 & 10.8 \\
Romania & 40.2 & 1.0 & 11.8 \\
Slovak R. & 8.6 & 4.9 & 1.9 \\
Slovenia & 16.0 & 14.2 & 6.1 \\
CEE & 19.8 & 7.2 & 7.0 \\
EU15 & 14.6 & 13.0 & 18.1 \\
\hline
\end{tabular}

- Data not available

a) 2000

b) 2001

Source: Eurostat

Although the incidence of irregular jobs has risen in transition economies, it is still low in the comparative perspective. However, one should bear in mind, that the comparison is limited to the formal sector, while the majority of casual and temporary jobs are in the informal sector. Given that the size of the informal sector is much larger in transition economies than in the EU, the actual incidence of irregular or casual jobs is likely to be correspondingly higher, too.

The growing use of fixed-term contracts is a means to lower employment adjustment costs if terminating a permanent employment contract is difficult or costly. Thus, their incidence can be expected to be higher in countries where firing costs are high, although restrictions on their use may hamper this tendency. Croatia and Slovenia, countries where the employment protection legislation is particularly stringent are the cases in point.

To conclude, it is not only the number of jobs but their "quality", including earnings, that matter. The relevant question is not only the standard one "How many jobs", but also one that is often overlooked, which is "What kind of jobs". There is limited but rather plausible evidence that there has been a switch from stable regular jobs towards temporary, casual and precarious jobs, partly in the formal sector, but largely in the informal one.

\section{Inter-sectoral shifts and the changing structure of employment}

Economic transition in ECA by its very nature has been associated with the reallocation of labor and jobs across economic sectors. One part of this process has been a shift of resources, including labor, from the public to the private sector. Another part - which is the focus of this section -- has been the movements of labor across industries. Reallocation of labor across industries was meant to redress the misallocation of resources inherited from the previous economic regime. Under central planning industry was overdeveloped while the service sector was underdeveloped. Thus, one would expect, that transition will lead to the increase in the 
relative size of the services sector and a simultaneous decrease in the size of the industry (manufacturing) sector. That is what has indeed happened, although the patterns vary across sub-regions. In European transition economies the service sector has expanded at the expense of the agriculture sector and to somewhat lesser extent at the expense of the manufacturing sector. ${ }^{4}$ In Belarus, Russia and Ukraine the services sector has expanded largely at the expense of the manufacturing sector, while the fall in the share of the agricultural sector was less pronounced. In other CIS the direction of structural change has been different. In contrast to European transition economies, the share of agriculture has significantly increased in virtually all lowincome CIS countries. As elsewhere, the manufacturing sector has diminished, however the service sector has hardly expanded.

Estonia provides perhaps the most dramatic example of the change in the employment structure. The market services sector expanded by 14 percentage points from 1990 through 2002, while agriculture and manufacturing contracted by 14 and 5 percentage points, respectively. In Poland changes were less dramatic but more typical of European transition economies. Market services as a share of total employment went up by 7 percentage points, whereas agriculture dropped by 5 percentage points and manufacturing by 4 percentage points (from 1994 through 2002). In Russia de-industrialization was more pronounced, as the share of manufacturing decreased by as much as 12 percentage points, however market services expanded at a slower pace, their share increasing by mere 2 percentage points (from 1990 through 1999). The example of Azerbaijan is quite typical of the low-income CIS. The share of agriculture increased by some 4 percentage points (form 1990 through 2002). So, did the share of market services, which went up by 5 percentage points. At the same time, the share of manufacturing dropped dramatically by 13 percentage points. ${ }^{5}$

Transition economies differ substantially as regards the sectoral structure of employment. In CEE the economy is dominated in equal measure by manufacturing and market services (jointly about 60 percent of all jobs). Public services (health, education, administration, etc.) provide additional 25 percent of jobs. The share of agriculture is relatively small (15 percent). Outliers in this group are Bulgaria and Romania, where the share of agriculture is well above the average for the group. If the group is limited to current EU member transition economies, then the share of agriculture is correspondingly lower, and that of manufacturing is higher.

In Belarus, Russia and Ukraine relatively more jobs are provided by agriculture and public services at the cost of significantly smaller market services sector. Belarus, Russia and Ukraine apparently move towards similar sectoral employment structure as CEE, however the pace of structural changes is slower and thus the economic structure seems "less advanced".

In the other CIS countries the employment structure looks dramatically different. It is heavily dominated by agriculture, which accounts for close to half of total employment. The manufacturing sector tends to be small, providing on average less than 15 percent of all jobs. The market services sector is also substantially smaller than in other ECA sub-regions, accounting for less than 20 percent of all jobs. Only the share of public services (which is the least varying component of the employment structure) is comparable to that in other ECA transition economies.

\footnotetext{
4 This does not necessarily imply that labor has moved directly from agriculture to services. An alternative scenario is also possible that agricultural labor moved to manufacturing and manufacturing labor moved to services. Data which would allow one to discriminate between those two scenarios is absent.

5 These figures come from an employer based survey, and thus probably underestimate the growth in the employment share of the services and agriculture sectors.
} 
Changes in employment structure are important in at least two ways. First, they tend to have far reaching labor market ramifications. Reallocation of labor across industries and sectors entails also reallocation across occupations and regions and as such is likely to give rise to structural mismatches. Jobs that are created in expanding industries usually require different skills and are located in different regions than jobs that are destroyed in declining industries. Particularly, the shift from industry to market services has been associated with a shift from bluecollar jobs to white-collar jobs requiring different skills. This imposes transition costs (in terms of time and effort) on workers who move from old to new jobs. Moreover, massive job and worker reallocation contributes to frictional and structural unemployment (when the skill and vocational structure of job openings differs from that of the unemployment). Accordingly it partially accounts for he high unemployment rates associated with the economic transition.

Second, the employment structure is an indicator of the level of economic development as well as the progress of the transition. In the particular case of transition economies, the share of market services, which was abnormally small before the transition, is a measure of successful labor reallocation. Figure 6 provides a ranking of ECA countries on this scale, indicating the progress of the transition toward a mature market economy.

\section{Figure 6 Market services account for a much larger share of employment in European transition economies than in the CIS.}

Market Services as a Percentage of Total Employment, 2002

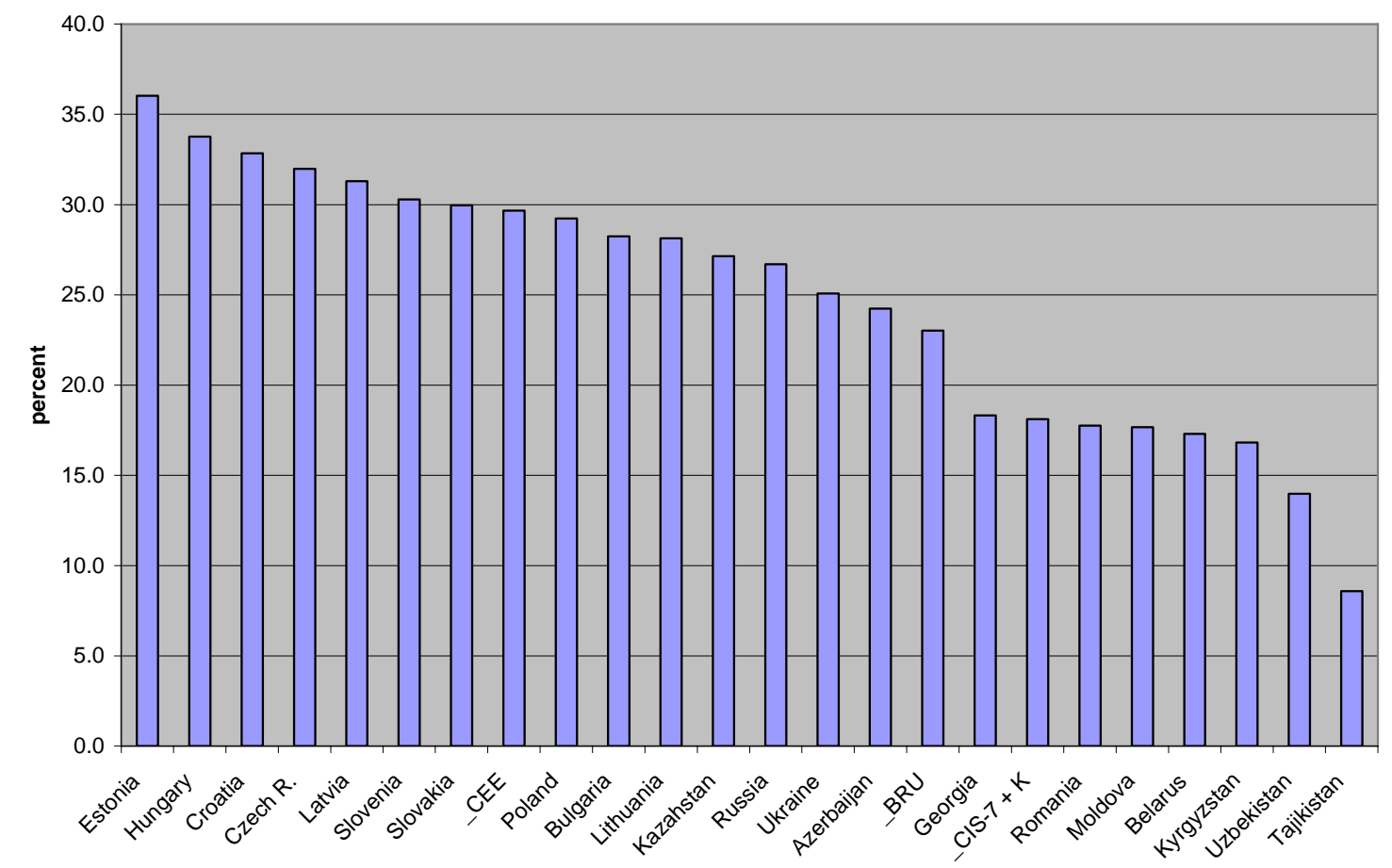

Source: ILO LABORSTA database (LFS data)

The employment share of market services is the highest in fast reforming and most advanced transition economies, such as Estonia, Hungary, and the Czech Republic (above 30 percent), and is the lowest in slow reforming and less advanced economies, such as Belarus and most of the low-income CIS countries (below 20 percent). 


\section{KEY FEATURES OF UNEMPLOYMENT IN TRANSITION ECONOMIES}

The unemployment rate is customarily used as a key indicator of labor market conditions. There are important reasons for this. First, the unemployment rate is an indicator of the overall health of the economy. High and persistent unemployment usually points to unresolved structural problems. Second, unemployment is very costly from both the individual and the social perspective. Job loss is associated with the loss of income, and often leads to poverty. Prolonged unemployment leads to the erosion of skills and morale, and often to social marginalization. To help the unemployed cope with joblessness the state provides income support and services intended to place the unemployment back to jobs. Such programs are costly and increase the burden of taxation. Finally, high unemployment can be costly politically, as in voters' opinion the government is responsible for ensuring job opportunities and good employment prospects. Thus high and rising unemployment poses a significant political risk for the ruling parties.

\section{Open unemployment in European transition economies and hidden unemployment in the CIS}

The transition shock has led to underutilization of labor in virtually all transition economies. But the underutilization of labor has taken different forms depending on the speed of market oriented reforms. Rapid enterprise restructuring has led to the growth in open unemployment. In contrast, the gradual approach to restructuring resulted in hidden unemployment (underemployment or low-productivity employment).

In Central and Eastern Europe unemployment was virtually nonexistent under central planning, but has risen sharply already at the early stage of the transition. This was an unavoidable and expected process, since some degree of unemployment (the so called "natural" unemployment rate) is characteristic of a market economy. Frictional unemployment is a natural product of workers moving across jobs in search of better worker-job matches and associated higher earnings. However, the rise in unemployment at the early stage of the transition had additional sources. First, the substantial drop in output translated into lower labor demand and gave rise to demand deficiency unemployment. Second, as mentioned earlier, massive labor and job reallocation associated with economic restructuring engendered structural mismatches which contributed to structural unemployment. Finally, enterprises which become subject to competitive pressure had to cut cost in order to remain profitable. Accordingly, they started to shed redundant labor and eliminate overstaffing typical of state owned firms.

These factors caused unemployment in most CEE economies to peak 4-5 years after the beginning of market oriented reforms. The CEE average unemployment rate reached about 12 percent in the peak period 1994-95 and started do go down since then until 1998 when it reached the through of 10 percent (Figure 7). In 1999 unemployment in the region rose again in response to the Russian crisis and global financial turmoil, and the second peak occurred in 2001. While the initial increase in unemployment was caused by factors specific to the transition, the increase in the wake of the Russian crisis was mainly of cyclical nature.

In Southeastern Europe (which is largely former Yugoslavia) unemployment existed even before the transition. In this case the transition shock (as well as the regional war) led to an increase in the unemployment rate to levels still higher than those in CEE. For example in FYR Macedonia the unemployment rate is about 30 percent and in Croatia it is close to 20 percent. The unemployment rate has also been gradually rising in Serbia and Montenegro, which have started the market oriented reforms later than other countries in the region. 
Figure 7 Unemployment fluctuates with changes in business conditions, but remains high in CEE countries

Unemployment Rate, 1992-2002

CEE

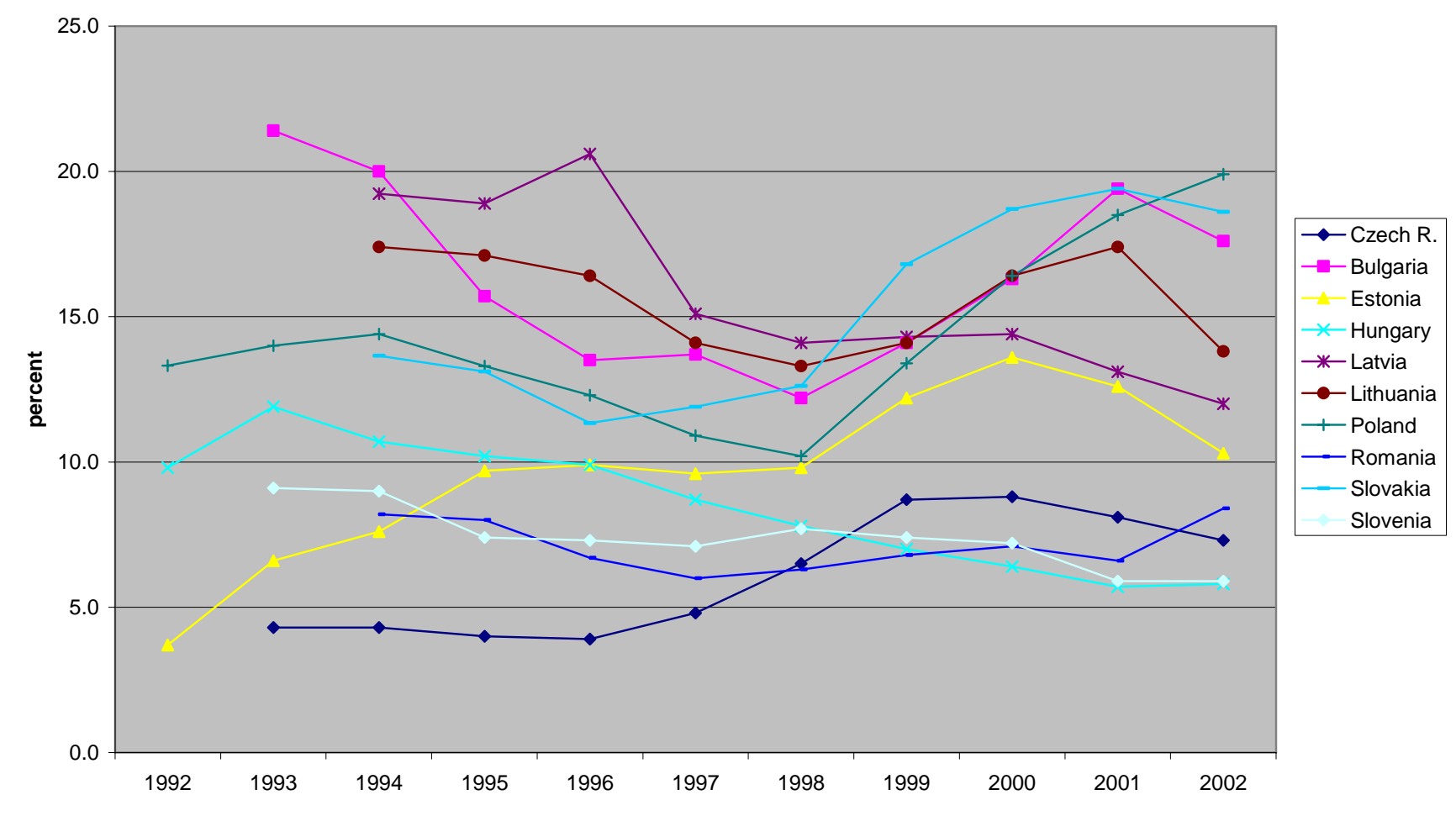

Source: ILO LABORSTA database (LFS data)

In Russia and Ukraine the evolution of unemployment has been somewhat different from that in CEE. Unemployment reached its peak later, only in 1998 (i.e. four years later than in $\mathrm{CEE}$ ). This is likely to reflect delayed restructuring and initially heavier reliance on wage adjustment (as opposed to employment adjustment) in response to the negative output shock. Since 1999 unemployment in both Russia and Ukraine has begun to decline. Again, it is too early to tell whether or not this decline represents a transitory movement, or a movement toward the equilibrium unemployment rate. Unemployment in Russia and Ukraine coincides with significant underemployment among workers in unrestructured firms or workers employed in the large informal sector. This is a still bigger problem in other CIS countries.

In the low-income CIS countries unemployment has also increased, but the problem is not so much open unemployment as underemployment. It takes the form of employment in subsistence agriculture, irregular or casual employment in the informal sector (e.g. petty trade), or employment in unprofitable and unviable enterprises, which often are not even able to pay wages. Underemployment is closely associated with low productivity and thus translates into lower output and social welfare, similarly as does unemployment. In a way, underemployment is a mirror image of unemployment in societies where people cannot afford to be unemployed, because there is no effective social safety net in place. 


\section{Unemployment rates vary strongly across the region but are generally high}

The unemployment rates are on average higher in European transition economies than in the CIS. In the CIS the LFS/ILO unemployment rate hovers around 10 percent showing relatively little cross-country variation. In contrast, in CEE the average unemployment rate was 12 percent in 2002, with visible intra-regional variation. The average unemployment rate in SEE is still higher (20 percent if FYR Macedonia is included, 14 percent if it is not.).

Overall, unemployment in transition economies is relatively high, significantly above the average of the OECD ( about 7 percents). In low unemployment CEE countries the unemployment rate is still significantly higher than in low unemployment EU15 economies. For example, the unemployment rate in the Czech Republic (7.3 percent in 2002) is significantly above that in Denmark and Ireland or the U.K. (about 5 percent). This discrepancy between the level of unemployment in transition economies, which still undergo industrial restructuring and are more exposed to shocks, and market economies with flexible labor markets is obviously not surprising. The point is that currently unemployment in transition economies is probably above its long-run equilibrium level, provided that the OECD is an adequate benchmark.

Despite the apparently similar initial conditions and similar experience of the transition, the unemployment rates vary strongly across transition economies. For example in Poland the unemployment rate was over 3 times higher than in Hungary $(20$ percent against 6 percent in 2002). In Slovakia the unemployment rate is 2.5 times as high as in the Czech Republic (19 percent against 7 percent). Even stronger differentiation of labor market conditions exists among countries of former Yugoslavia. The unemployment rate in FYR Macedonia is over 5 times as high as in Slovenia, and in Croatia the rate is 2.5 times as high as in Slovenia. Figure 8 illustrates this huge dispersion in unemployment rates in ECA.

\section{Figure 8 Unemployment rates vary strongly across transition economies}

Unemployment rate, 2002

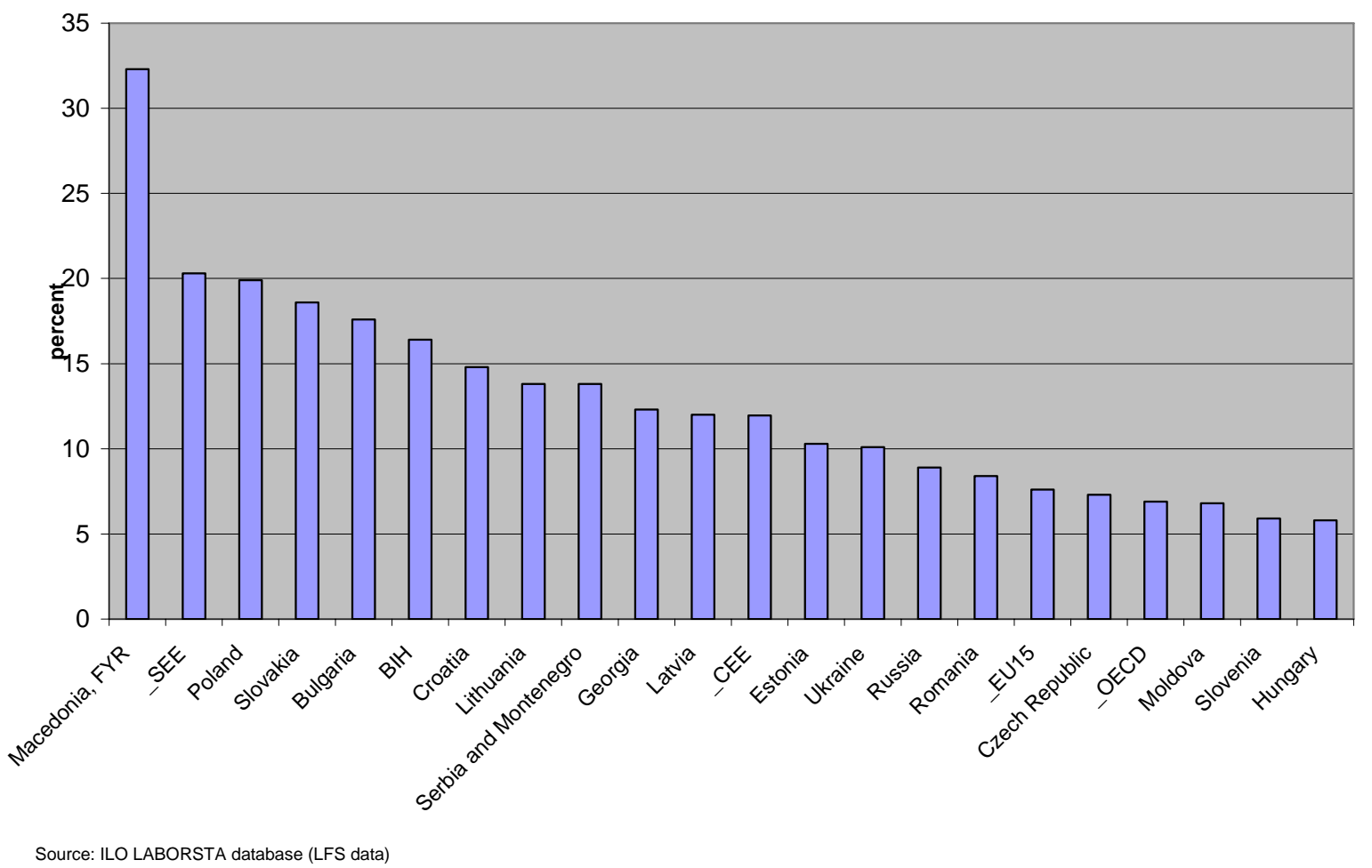




\section{Inflows into unemployment are high while outflows are limited}

The level of unemployment depends on the probability of becoming unemployed, and on the expected duration of the unemployment spell. The latter in turn depends on the probability of escaping unemployment. Accordingly, the level and the durational structure of unemployment vary depending on the relationship between the inflow rate and the expected duration of unemployment (probability of escaping unemployment). In a simple way this relationship is depicted in Table 4.

\section{Table 4 Labor flows and unemployment}

\begin{tabular}{|c|c|c|}
\hline \multirow[t]{2}{*}{$\begin{array}{l}\text { Inflows into unemployment } \\
\text { - employment to unemployment } \\
\text { - inactivity to unemployment }\end{array}$} & \multicolumn{2}{|c|}{$\begin{array}{l}\text { Outflows from unemployment } \\
\text { - unemployment to jobs } \\
\text { - unemployment to inactivity }\end{array}$} \\
\hline & $\begin{array}{l}\text { High: dynamic labor } \\
\text { market }\end{array}$ & $\begin{array}{lll}\text { Low: } & \text { stagnant } & \text { labor } \\
\text { market } & & \end{array}$ \\
\hline High & moderate unemployment & high unemployment \\
\hline Low & Low unemployment & moderate unemployment \\
\hline
\end{tabular}

Unemployment can have different durational structure. For example, in a dynamic labor market the risk of losing a job may be high, but so is are the chances of finding a new one. Accordingly the expected duration of unemployment will be short, which will result in a "moderate" unemployment rate (or low unemployment rate if inflows into unemployment are low).

An opposite example is that of a stagnant labor market. In such a market the risk of losing a job may be low, but the prospects of finding a new one are poor. The expected duration of unemployment spells will be long and level unemployment will be elevated despite low inflows into joblessness. If inflows into joblessness increase (e.g. due to economic downturn, restructuring, or demographical pressures), unemployment will reach a high level.

A typical example of a flexible, dynamic labor market is the U.S. Indeed, 66 percent of the unemployed find a job within a year (Boeri and Terrel, 2002). The median duration of unemployment fluctuates around 10 weeks and correspondingly the incidence of long term unemployment is very low (less than 10 percent).

Labor markets in transition economies are in sharp contrast to the dynamic labor market, such as the US. ${ }^{6}$ Expectedly, flows from employment to unemployment are higher, as transition economies undergo rapid restructuring, which be its very nature is associated with a high rate of job destruction. For example, the flows from employment to jobs in Poland or Russia in the mid 1990 were roughly twice those in the US. However, the outflow rate from unemployment to jobs is also much lower in the transition economies than in the U.S., showing that the rate of job creation is too low to absorb the accumulated unemployment pool. The chance that a worker finds a job within a year after entering unemployment is in virtually all transition economies substantially smaller that in the US. Roughly speaking, the probability that an unemployed persons find a job is in transition economies half that in the US. Thus, all else being equal, if the outflow rate from unemployment to jobs in Poland, say, were the same as in the US then the

\footnotetext{
${ }^{6}$ Data on labor flows is available for CEE countries and Russia but not for other CIS countries.
} 
Polish unemployment rate would be by about one-fourth lower. ${ }^{7}$ Some examples of the differences in flows into and out of unemployment are shown in Table 5.

Table 5. Jobless workers in transition economies face low chances of escaping unemployment

\begin{tabular}{|c|c|c|c|c|c|c|c|}
\hline Country & Year & $\begin{array}{c}\text { Employment } \\
\text { to } \\
\text { Unemployme } \\
\text { nt }\end{array}$ & $\begin{array}{l}\text { Employment } \\
\text { to Out of the } \\
\text { Labor Force }\end{array}$ & $\begin{array}{l}\text { Unemployme } \\
\text { nt to } \\
\text { Employment }\end{array}$ & $\begin{array}{l}\text { Unemployment } \\
\text { to Out of the } \\
\text { Labor Force }\end{array}$ & $\begin{array}{l}\text { Out of the } \\
\text { Labor Force } \\
\text { to } \\
\text { Employment }\end{array}$ & $\begin{array}{c}\text { Out of the } \\
\text { Labor Force } \\
\text { to } \\
\text { Unemployme } \\
\text { nt }\end{array}$ \\
\hline \multicolumn{8}{|c|}{ Central and Eastern European Countries } \\
\hline Bulgaria & 1994-1995 & 0.059 & 0.092 & 0.323 & 0.244 & 0.092 & 0.044 \\
\hline Czech. R & 1994-1995 & 0.013 & 0.028 & 0.496 & 0.129 & 0.042 & 0.012 \\
\hline Czech. R & 1996-1997 & 0.08 & 0.025 & 0.457 & 0.101 & 0.04 & 0.008 \\
\hline Czech. R & 1998-1999 & 0.018 & 0.025 & 0.335 & 0.09 & 0.036 & 0.017 \\
\hline Poland & 1992-1993 & 0.04 & 0.076 & 0.361 & 0.158 & 0.095 & 0.045 \\
\hline Poland & 1993-1994 & 0.04 & 0.063 & 0.354 & 0.159 & 0.074 & 0.043 \\
\hline Slovakia & 1994-1995 & 0.023 & 0.045 & 0.237 & 0.078 & 0.018 & 0.017 \\
\hline \multicolumn{8}{|c|}{ Former Soviet Union } \\
\hline Estonia & 1992 & 0.048 & 0.097 & 0.465 & 0.093 & 0.143 & 0.036 \\
\hline Estonia & 1997 & 0.047 & 0.04 & 0.372 & 0.064 & 0.074 & 0.038 \\
\hline Russia & 1992-1993 & 0.032 & 0.058 & 0.52 & 0.157 & 0.087 & 0.014 \\
\hline $\begin{array}{l}\text { Russia } \\
\text { United }\end{array}$ & $1995-1996$ & 0.056 & 0.062 & 0.395 & 0.145 & 0.076 & 0.034 \\
\hline States & $1992-1993$ & 0.028 & 0.053 & 0.659 & 0.288 & 0.043 & 0.161 \\
\hline
\end{tabular}

Source: Boeri and Terrel (2002)

Data in Table 5 suggest that initially high unemployment in transition economies was the product of relatively high inflows into unemployment and limited outflows to jobs. Most of the economies were thus in the high unemployment/depressed (stagnant) labor market state.

As the restructuring process slowed down with the progress of the transition, the initially high inflow rates gradually declined, although they still remain higher than in a mature market economy, such as the US. This entailed a movement toward the moderate unemployment/stagnant labor market state, as the job finding chances hardly improved and thus the duration of unemployment remained high. At this stage unemployment is a stagnant pool: few workers enter unemployment but also few are able to exit it.

Recent examples of a substantial fall in unemployment in some CEE countries (e.g. Lithuania) suggest that these successful countries might have begun a movement toward moderate unemployment/dynamic labor market and eventually. It is obviously an open question if the movement will continue toward the low unemployment/dynamic labor market state.

\footnotetext{
7 Outflows from unemployment to jobs account for about two-thirds of all outflows from unemployment (the other being to inactivity), so doubling the outflows to jobs rate (holding the outflows to inactivity rate constant) results in shortening of the average duration of unemployment and thus lowering the unemployment rate by one-fourth.
} 


\section{Long duration of unemployment}

Poor employment opportunities along with skill and location mismatches lead to long duration of unemployment, which is the mirror image of low exit rates from unemployment, which prevail in transition economies. As a result, transition economies have seen the growth in the incidence of long-term unemployment. Presently the long term unemployment in CEE accounts for over 50 percent of total unemployment, which is much more than in EU, where it accounts for 40 percent. (Figure 9). After all, in the flexible, well performing EU labor markets the incidence of long-term unemployment at around 25 percent is still much lower. It is noteworthy, that in every EU transition economy the incidence of long-term unemployment is higher than the already high EU average. In Latvia, where long term unemployment is the least prevalent among European transition countries, it still accounts for 45 of total unemployment. Bulgaria is an extreme case, with two-thirds of all the unemployed suffering from long-term joblessness.

\section{Figure 9: Long-term unemployment looms large in all European transition economies}

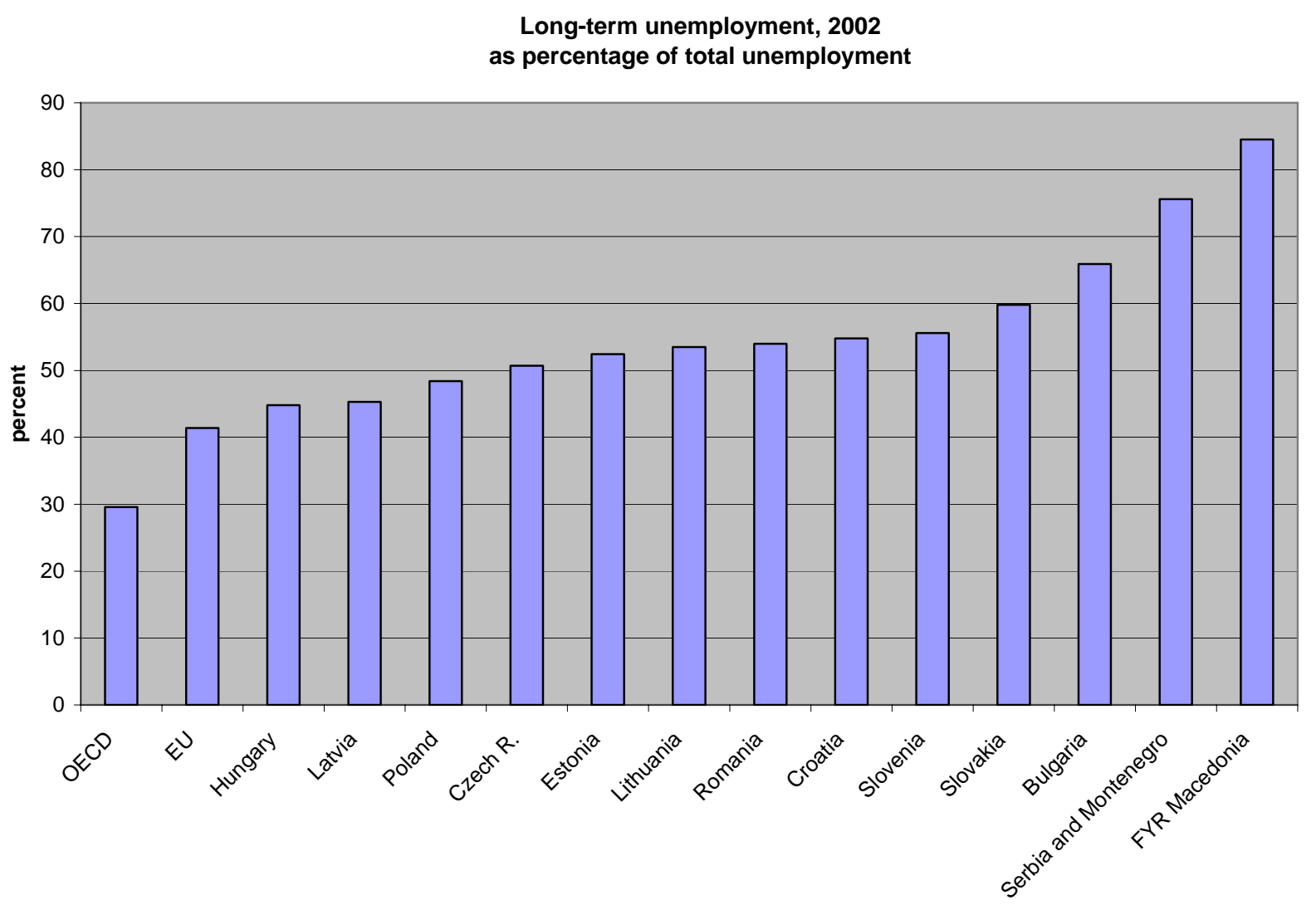

Source: Eurostat, OECD (2003) and national Statistcal Offices; Bank staff calculations.

The problem of long duration of unemployment is even more severe in the Southeastern transition economies, such as Croatia and FYR Macedonia, where stringent employment protection legislation has for long discouraged employers from hiring. This has led to the accumulation of a large pool of workers who find it extremely difficult to enter or re-enter the labor market (World Bank, 2003c; Rutkowski, 2003c).

To conclude, the high incidence of long-term unemployment in most transition economies points to a depressed, stagnant labor markets and possibly to structural mismatches. Once unemployed, people have little chances to find new employment. Long duration of 
unemployment spells is associated with high individual and social costs. It tends to cause the erosion of human capital, and often leads to poverty and social exclusion. Accordingly it is the high long-term unemployment rates prevailing in ECA transition economies which are of particular policy concern.

\section{High unemployment among less skilled workers}

Unemployment in the European transition economies is heavily concentrated among less educated workers. Generally, the unemployment rate is the higher, the lower is the educational level (Table 6). Unemployment rates among workers with primary and lower secondary education tend to be extremely high, usually well above 20 percent. They are significantly lower - although often still high -- for workers with upper secondary education, on average around 13 percent. The unemployment rate drops dramatically to 4 percent for workers with university education (the $\mathrm{CEE}$ average). It is noteworthy that the unemployment rate for university educated workers tends to be low even in high unemployment countries, such as Bulgaria (8.5 percent) or Poland (5.6 percent), suggesting that the fall in labor demand has been biased against the less skilled workers. A notable exception is FYR Macedonia, where the unemployment rate is very high even among workers with tertiary education (16.6 percent), although still half the overall unemployment rate. This exception notwithstanding, university education seems to be the best protection against unemployment in the European transition economies. Unfortunately, lack of relevant data makes it impossible to ascertain whether or not this result holds also for other ECA countries.

Table 6 Unemployment hits less educated workers particularly strong

\begin{tabular}{|c|c|c|c|}
\hline & $\begin{array}{l}\text { Less than } \\
\text { upper } \\
\text { secondary }\end{array}$ & $\begin{array}{c}\text { Upper } \\
\text { secondary }\end{array}$ & Tertiary \\
\hline \multicolumn{4}{|l|}{ CEE } \\
\hline Bulgaria & 33.1 & 19.4 & 8.8 \\
\hline Czech Republic & 21.5 & 7.1 & 2.5 \\
\hline Estonia & 18.6 & 13.3 & 8.0 \\
\hline Hungary & 11.2 & 5.2 & 1.2 \\
\hline Latvia & 21.0 & 13.0 & 5.5 \\
\hline Lithuania & 23.1 & 21.7 & 10.1 \\
\hline Poland & 23.9 & 19.4 & 5.6 \\
\hline Romania & 4.0 & 8.6 & 3.9 \\
\hline Slovakia & 42.5 & 18.7 & 5.2 \\
\hline Slovenia & 8.9 & 5.5 & 2.3 \\
\hline \multicolumn{4}{|l|}{ SEE } \\
\hline Croatia a) & 13.7 & 16.7 & 7.6 \\
\hline Macedonia, FYR & - & - & - \\
\hline Serbia and Montenegro a) & 24.9 & 19.7 & 9.5 \\
\hline \multicolumn{4}{|l|}{$\begin{array}{l}\text { - Data not available } \\
\text { Note: Labor Force Survey } \\
\text { data } \\
\text { a) } 2002 \\
\text { Source: }\end{array}$} \\
\hline \multicolumn{4}{|l|}{ CEE: Eurostat } \\
\hline
\end{tabular}


Although workers with primary education face a high risk of unemployment, they ere not numerous in most European transition economies, where most of the labor force has at least lower secondary education. Given their high share in the labor force and the relatively high unemployment rate among this group, it is workers with secondary education which are preponderant among the unemployed.

Less skilled workers have lower chances to find work, and accordingly face longer unemployment spells. As a result, they are disproportionately represented among the long-term unemployed. For example, in Poland workers with less than upper secondary education accounted for 60 percent of short term unemployment, and 65 percent of long-term unemployment (2002 data).

Disproportionately high unemployment among less skilled workers is a common phenomenon in developed countries, and transition economies are no exception in this regard. These high unemployment rates are explained by technological change which tends to be biased against less skilled manual labor. At the same time, new generations of capital require higher skills, which explains demand for well educated workers. A more in depth analysis of the changing demand for skills in transition economies is provided in Commander and Kollo (2004).

\section{High youth unemployment}

An issue of particular concern in transition economies is high youth unemployment. Indeed young workers (15-24) face the risk of unemployment much higher than that faced by older workers. In most cases the youth unemployment rate is about twice as high as the overall unemployment rate (Table 7). However, relatively high youth unemployment rates are typical of all developed countries. In EU/OECD countries the ratio of the youth unemployment rate to the overall unemployment rate is virtually the same as in transition economies. What distinguishes transition economies from OECD economies is high absolute youth unemployment rates, rather than high relative rates. 
Table 7 Unemployment rates are particularly high among young workers

\begin{tabular}{lrr}
\hline & $\begin{array}{c}\text { Youth unemployment } \\
\text { as \% of labor force 15- } \\
\text { 24 }\end{array}$ & $\begin{array}{c}\text { Youth unemployment } \\
\text { rate/overall } \\
\text { unemployment rate }\end{array}$ \\
\hline CEE & 35.5 & 2.0 \\
Bulgaria & 16.9 & 2.3 \\
Czech R. & 17.7 & 1.9 \\
Estonia & 11.9 & 2.1 \\
Hungary & 24.6 & 1.9 \\
Latvia & 21.4 & 1.6 \\
Lithuania & 41.7 & 2.1 \\
Poland & 18.5 & 2.6 \\
Romania & 37.3 & 2.0 \\
Slovakia & 15.3 & 2.6 \\
Slovenia & 17.8 & 1.6 \\
Turkey & & \\
SEE & & 2.4 \\
Croatia & 34.5 & 3.1 \\
Serbia and Montenegro & & 1.9 \\
a) & 58.0 & 2.0 \\
Memorandum & & 1.9 \\
\hline EU15 & & \\
OECD Europe & 14.7 & \\
Total OECD & 17.6 & \\
\hline NOte: Labor Force & 13.1 & \\
\hline
\end{tabular}

Note: Labor Force Survey data

a) The unemployed include persons who in the reference period did a temporary job

Source:

CEE and EU: Eurostat

Turkey and OECD: Employment Outlook, OECD

Croatia: Central Bureau of Statistics, Labour Force Survey 2002 (second half), Bank staff calculations.

Serbia and Montenegro: Republic of Serbia, Republican Statistical Office, Labor Force Survey 2002 (October),

Bank staff calculations

For example, in Poland youth unemployment rate is above 40 percent. In Bulgaria and Slovakia it is between 35 and 37 percent. On average, the youth unemployment rate in CEE is close to 25 percent. This is almost twice as high as the average youth unemployment rate for the OECD countries. Unemployment rates of such magnitude are likely lead to social tension.

The disproportionately high youth unemployment rates largely reflect higher levels of labor turnover among young workers, who tend to change jobs more often than older workers, presumably looking for the best worker-job match. However, they may also be associated with labor market rigidities and barriers created by stringent employment protection legislation, which favors insiders (workers with secure jobs) at the cost of outsiders (the unemployed, contingent workers). For example, an extremely high fraction of young labor market entrants among the unemployed in FYR Macedonia can be at least partly attributed to high degree of job protection granted to incumbent workers (World Bank, 1998). Another possible source of high youth unemployment is the minimum wage set at above market clearing level. For example, in economically depressed, high unemployment regions of Poland the minimum wage accounted 
for over 80 percent of the going wage rate for low skilled workers. Given that many young workers lack labor market experience and skills, they are likely to be negatively affected by high minimum wages (World Bank, 2001; Kertesi and Kollo, 2003; Rutkowski 2003a,). These considerations led the Polish government to introduce a youth sub minimum wage accounting for 80 percent of the adult minimum wage in 2002 .

Youth unemployment matters because evidence shows that it is often associated with poverty. A priori this is not an obvious result, as it may be the case that young people looking for work are predominantly secondary earners in relatively well-to-do families, who just want to earn additional income. However, in many transition economies the unemployed youth live in poverty. For example, in Macedonia and Bulgaria the incidence of poverty among the unemployed youth is significantly higher than the average (World Bank 1999; Rutkowski, 1999),. In this case the likely reason is that young people in poor families cannot afford to be out of the labor force. Low family income forces people to enter the labor market at a relatively young age. As long as young people are searching for jobs they are counted as the unemployed, and in this sense poverty gives rise to youth unemployment. Obviously, prolonged and unsuccessful job search by young family members can also contribute to poverty. Either way, youth unemployment has significant negative poverty effects. The issue of youth unemployment in SEE is explored in more detail in Kolev and Saget (2003).

\section{Large and persistent regional disparities in labor market conditions}

There are substantial disparities in labor market conditions in most ECA countries. Most regions are economically depressed with high unemployment rates, often coupled with low labor force participation rates (in large part due to the "discouraged worker" effect) and, consequently, low employment rates. In these regions the job creation and hiring rates are low, severely limiting the chances to escape unemployment. At the same time, in a small number of expanding regions unemployment is relatively low, the job creation rate is high, and employment opportunities are plentiful. Table 8 illustrates a particular dimension of regional labor market imbalances: differences in the unemployment and employment rates.

The dispersion in unemployment rates in the six European transition economies in the sample is substantial. The unemployment rate in the highest unemployment region is in most cases at least twice as high as in the lowest unemployment region (with Poland being an exception). ${ }^{8}$ For example, in Bulgaria the unemployment rate in north-west region is 32 percent, compared with 16 percent in the south-western region (see Annex Table A1). The differentials increase with the level of regional dis-aggregation, i.e. when the analysis concerns a larger number of smaller regions. Particularly, if the capital region is shown separately then the disparity between the highest and the lowest unemployment region becomes even more pronounced. For example, the unemployment rate in the highest unemployment region of Slovakia is almost tree times as high as in the capital region (24.5 percent and 8.5 percent, respectively).

Regional unemployment inequality reflects strong regional concentration of job creation and employment growth. Often it is only a few regions which create jobs on a net basis (that is where the job creation rates exceeds the job destruction rate) and where the jobless face good

\footnotetext{
8 The degree of regional variation of unemployment rates is influenced by the size of the regions (in general, the larger are the regional units, the lesser the variation). Thus the variation of unemployment rates is not comparable across countries, as regions differ in size. Nevertheless, the comparison gives a rough idea of the regional disparities in labor market conditions.
} 
employment prospects. In most regions the rate of job destruction still exceeds that of job creation implying net employment loss. If the number of jobs declines, chances to escape unemployment are poor. For example, in Bulgaria it is only the capital region, where employment expands (Rutkowski, 2003b). In Croatia employment grows only in 4 out of 21 regions, and in Poland in 3 out 16 regions (Rutkowski 2003c; World Bank 2001). So employment creation in regions of high unemployment has not picked up.

Regional labor market disparities are not specific to transition countries and occur also in developed market economies. However two factors are specific to European transition economies. First, most transition countries (including Russia) display a degree of variation in unemployment rates generally higher than most Western European countries, let alone the USA. For example, the coefficient of variation of unemployment for France and the USA is roughly half that for the Czech Republic and one third that for Hungary (Boeri and Scarpetta, 1996; Bornhorst and Commander, 2004). These large differences in regional unemployment rates are associated with strong concentration of net job creation in few relatively economically vibrant regions and the dominance of job destruction in most other, economically depressed, regions.

Second, labor market imbalances tend to be highly persistent in transition economies. The ranking of regions by the unemployment rate hardly changes over time. High unemployment regions at the early stage of the transition tend to remain relatively high unemployment regions today. This points to the weakness of equilibrating mechanisms, such as wage adjustment or inter-regional labor mobility to accommodate region specific shocks and lower regional imbalances (Boeri and Scarpetta, 1996; Fidrmuc, 2003, Huber, 2003a; Bornhorst and Commander, 2004).

Why are regional unemployment disparities so large in transition economies? There two factors at work. First, large region specific shocks to product and consequently labor demand. A study of regional unemployment in Poland found that higher unemployment regions are those experiencing greater change in industrial structure. Moreover, high unemployment regions are those with higher inflow rates to unemployment rather than longer spells of unemployment. These findings suggest that regional unemployment varies importantly with job destruction in Poland and thus region specific labor demand shocks (Newell, 2000).

Second, underlying structural factors, which determine regions' growth potential. These structural factors include sectoral and industrial structure, the degree of urbanization, the development of the infrastructure, and last but not least, human capital endowment. As regions in transition economies differ substantially with respect to their economic structure, these differences translate into differences in labor market conditions. Generally, regions which fare best in terms of job creation and employment prospects are urbanized (especially those with large agglomerations), with a large service sector, with developed infrastructure (both traditional and modern, such as telecommunication networks), and with well educated, skilled workforce. In contrast, regions which fare worst in terms of labor market conditions are industrial regions with obsolete, non-competitive, declining industries (especially heavy industries, such as steel or mining). The performance of agricultural regions is mixed. Agriculture is often an employer of last resort and thus open unemployment in agricultural regions is relatively low, but underemployment is considerable. The issue of factors accounting for regional unemployment inequalities and the typology of regions with respect of their labor market performance is analyzed in more depth in Huber and Scarpetta (1995), Scarpetta (1995), Rutkowski and Przybyla (2002), and Huber (2003b).

How to improve the employment prospects in high unemployment regions? European experience demonstrates that labor mobility and wage flexibility by itself play only a modest role 
and are insufficient to visibly lessen regional imbalances. The key to economic growth and thus better labor market conditions in depressed regions is investment and the consequent job creation. Thus, the challenge facing depressed regions is to attract investment, which requires creating incentives for firm entry, developing infrastructure, and investments in human capital to improve labor productivity.

To conclude, there are large regional unemployment disparities in transition economies, driven by region specific labor demand shocks as well as by regions' structural characteristics. Particularly, the response to these idiosyncratic shocks depends on structural factors, such as the sectoral structure, presence of strong urban centers, the skill composition of the labor force, and the development of the infrastructure. Regional unemployment inequalities tend to be persistent, pointing to the weakness of equilibrating mechanisms, such as wage adjustments and labor mobility. However, they may also reflect regional differences in steady-state unemployment levels. To overcome these disparities depressed regions need to be turned into attractive locations for private firms to invest and create jobs. This in turn requires public investments in infrastructure and human capital.

\section{WAGE DEVELOPMENTS}

Economic transition has been associated with profound changes in the wage level and structure (relative wages). Changes in the wage level represented a response to the changing level of output and productivity. Changes in the wage structure reflected changes in the wage setting mechanism (from bureaucratic and centralized one to a market based and decentralized one) as well as changes in the relative demand for and supply of different types of labor. A direct consequence the changes in the wage structure has been an increase in wage inequality. In the ensuing part of this section we analyze these developments in turn.

\section{Real wages have been growing in all transition economies since the mid 1990s}

After an initial sharp drop in the early 1990s, real wages in virtually all transition economies have been growing at a pretty high rate since the mid 1990s, following gains in labor productivity. ${ }^{9}$ However, the pattern of wage adjustment has differed considerably across ECA sub-regions. Generally, the wage drop has been much deeper in the CIS than in CEE. While in the CIS real wages are currently at around 50 percent of their pre-transition level, they close to it in CEE (Figure 10). After all in a few CEE countries wages are already higher than before the transition. Coupled with the earlier analysis of employment dynamics, these data suggest that while in CEE the brunt of adjustment to the transition shock was borne by employment, in the CIS it was borne by wages.

\footnotetext{
${ }^{9}$ In most transition economies real wages are still lower than before the transition, but this result needs to be treated with caution. The actual real wages decline was most probably much less then the measured one This is due to the fact that the pre-transition level of real wages was overestimated in most of the transition economies. This overestimation resulted from prices being set at below-the equilibrium level, as attested by pervasive consumer good shortages. If prices were set so as to equate the demand for and the supply of goods, as it is the case in a market economy, then real wages before the transition would be correspondingly lower. In other words, real wages before the transition were often not quite "real" in terms of consumer purchasing power. If this factor were taken into account, the reported wage drop would be much less, although the degree of the correction varies by country. In addition, wage data are likely to be affected by wage arrears and non-payment of wages, a problem particularly pronounced in CIS (particularly at the early stage of the transition). Finally, a widespread practice of underreporting of wages to avoid tax payments also means that the actual wage growth during the transition is likely to be underestimated.
} 
Figure 10 Real wages rebounded in the mid-1990s

Real Wage Growth

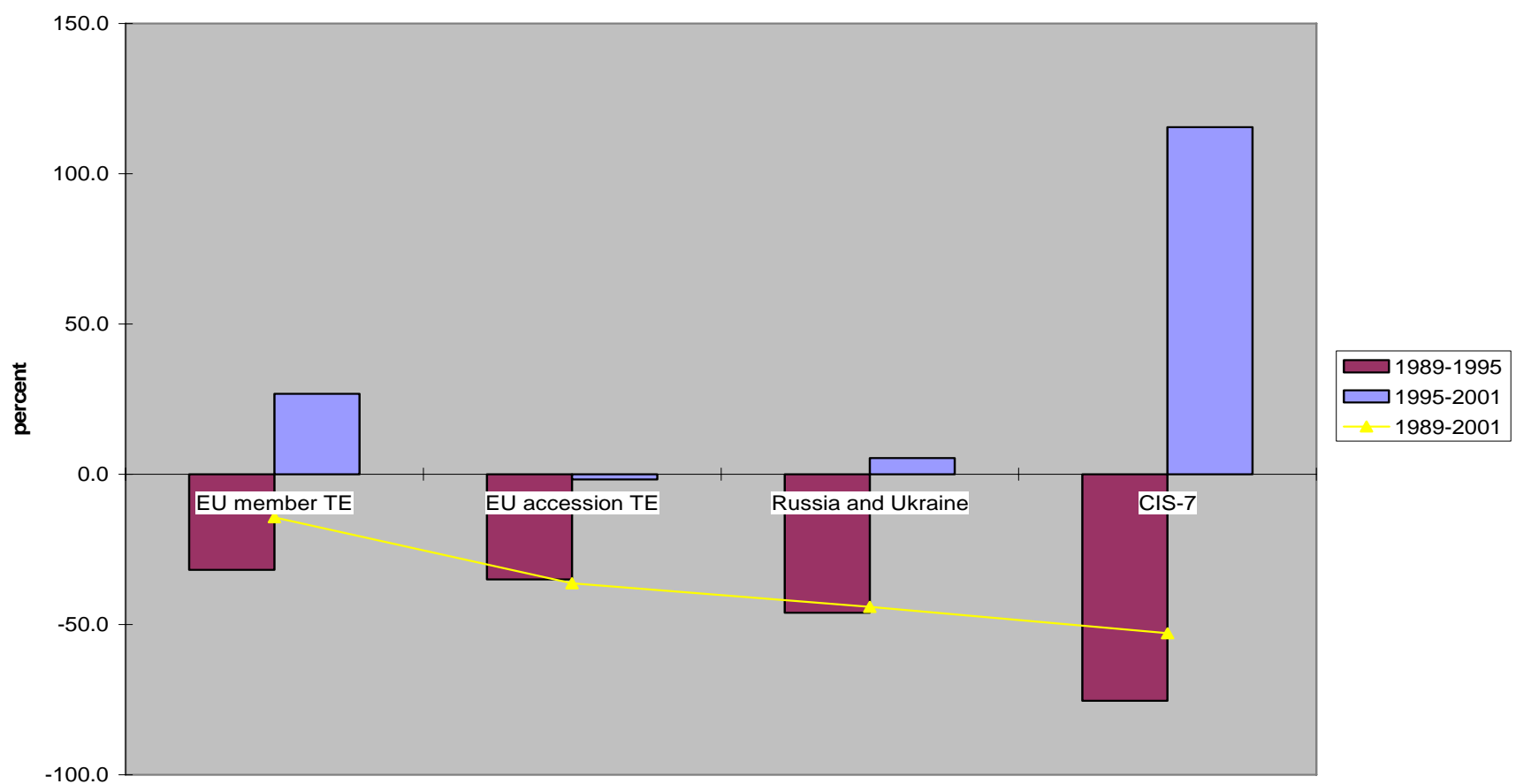

Source: UNICEF TransMONEE database; Bank staff calculations

Individual country experiences regarding wage dynamics vary strongly across the region (Figure 11). Among CEE, wages in the Czech Republic and Poland are almost 20 percent higher than before the transition and close to the pre-transition level in Hungary and Slovenia. At the same time, in Bulgaria and Lithuania wages much lower than before the transition.

Figure 11 Real wages are close to the pre-transition level in CEE countries and below it in CIS-7.

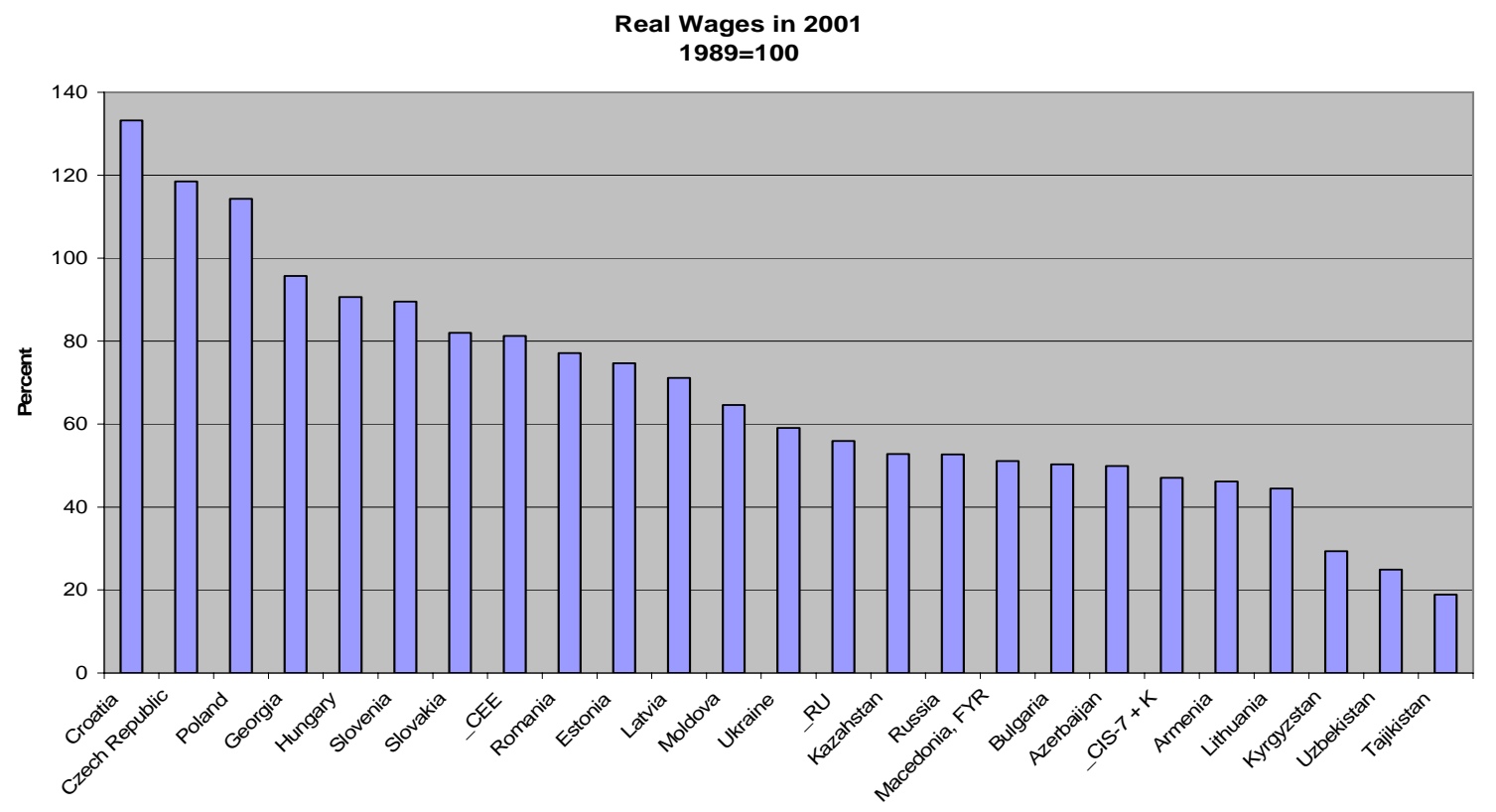

Source: UNICEF, TransMONEE database; Bank staff calculations. 
In the CIS the variation in wage growth has been much less than in CEE and in most cases wages are 40 to 50 percent lower than before the transition. However, in a few countries (Kyrgyzstan, Tajikistan, and Uzbekistan) according to official data wages are at only 30 percent or even less of their pre-transition level

\section{Wage drop was strongly concentrated in the early phase of the transition followed by a strong wage growth since the mid 1990s}

Wage dynamics in ECA transition economies mirrored that of output and productivity. Wages fell sharply during the first half of the 1990s, when output was contracting, and have begun to growth since the mid 1990s, when output and productivity started to rise. Figure 10 shows the dramatic drop in wages during the first phase of the transition, and the strong wage growth during the following phase.

It is worth noting, that the strong wage growth since the mid-1990s has occurred in all transition economies, with no exception. Thus, output and productivity growth, which followed the initial output collapse, have been translated into higher wages. Given that productivity growth has to a large extent been driven by eliminating labor hoardings and shedding of redundant labor, there has been a negative correlation between wages and employment growth. That is, the growth of wages was associated with the fall in employment. This renders the welfare effect of labor market developments during the second phase (associated with output recovery) of the transition ambiguous. There have been winners: employed insiders who enjoyed higher wages, and the outsiders, suffering from joblessness and income loss.

\section{Wage inequality has strong increased and reached high levels}

Wage inequality was relatively low in socialist countries, reflecting the egalitarian ideology. Wage grids were as a rule determined centrally, and specified the minimum and the maximum wage, with the latter being a pre-determined multiple of the latter. In some countries (e.g. Hungary, Poland) the system was somewhat more flexible, nonetheless wage distribution remained compressed either under the trade union pressure, or to buy social peace and maintain the legitimacy of the socialist system. The Gini coefficient, which is a summary measure of income inequality, was at a low level of 20-25 in European socialist economies and at somewhat higher level of around 25 in the Soviet Union (Atkinson and Micklewright, 1992). ${ }^{10}$

Wage distribution has widened considerably during the transition in all ECA countries, and wage inequality has reached high levels by international standards. However, there are substantial differences across country groups. Wage inequality tends to be higher in economically less developed countries. It is by far the largest in the low-income CIS, where the Gini coefficient is in the range of 45-50. In middle-income CIS the Gini coefficient ranges from about 35 in Belarus to over 40 in Ukraine, to nearly 50 in Russia. These values imply high levels of inequality by international standards. Wage disparities in the CIS are comparable to those in developing countries.

In European transition economies wage dispersion is significantly lower than in the CIS, but higher than the EU average. The Gini coefficient is in most cases in the range of 30-40, which is high by European standards. The Czech Republic stands out as relatively low wage inequality transition economy (Gini less than 30), while Romania and Serbia and Montenegro are at the other extreme (Gini about 40).

\footnotetext{
10 The Gini coefficient ranges from 0 , which indicates no inequality to 100 , which means that all income is received by one person. In practice, the Gini coefficient is ranges from 20 to 50 .
} 
Overall, there are quite substantial differences in the degree of wage inequality both between country groups and within groups. This variation in wage inequality is depicted in Figure 12. ${ }^{11}$

Figure 12 Summary of wage distribution, 2002

Summary of Wage Distribution, 2002

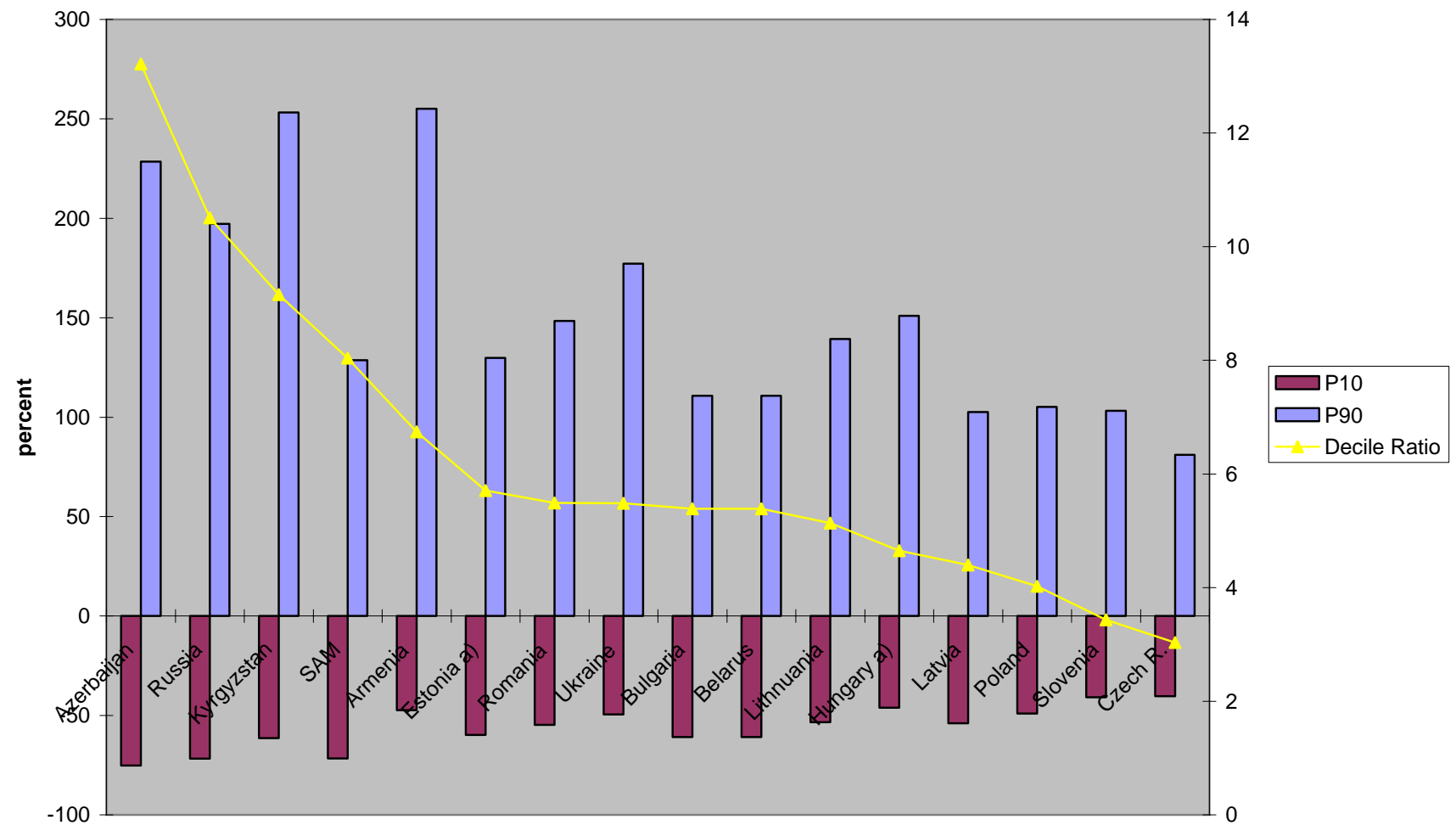

Source: UNICEF TransMONEE database; Bank staff calculation

a) 2001

$\mathrm{P}_{10}=$ bottom decile/median

$\mathrm{P}_{90}=$ top decile/median

Decile ration $=$ top decile/bottom decile

In the European transition economies the wage distribution has widened especially at the upper tail, meaning the high wages have become more prevalent and also the emergence of very high wages, not seen under the previous regime. For example, in Poland before the transition a top-paid workers (top decile) was earning 60 percent more than the median worker. At present a top paid worker earns twice as much a the median worker. Thus, the earnings status of top paid workers has improved quite substantially.

Changes at the lower tail of the wage distribution were less pronounced in CEE. Sticking to the example of Poland, which is quite typical, before the transition a low-paid (bottom decile) worker was earning 35 percent less than the median worker. Currently, a low-paid worker earns

\footnotetext{
${ }^{11}$ The measures of wage inequality shown in Figure 12 are defined as follows. The decile ratio is the ratio of the top decile wage to the bottom decile wage, and can be thought of a ratio of "high" to "low" wages. The P90 ratio is the ratio of the top decile wage to the median wage, and shows the relative wage position of top paid workers. The P10 ratio is the ratio of bottom decile wage to the median wage and shows the relative wage position of low-paid workers.
} 
half the wage of the median worker. This represents a significant although not a dramatic deterioration of the relative earnings status of low-paid workers.

In contrast, in the CIS the wage distribution has widened at both the lower and the upper tail, implying the emergence of very high and very low wages. Particularly, the earning status of low-paid workers has deteriorated in the CIS much more than in the European transition economies. For instance, in Russia before the transition a top paid worker was earning about 80 percent more than the median worker. Presently he/she earns tree times as much. A low-paid worker was earning 45 percent less than the median worker, now he/she earns about 70 percent less. This represents a dramatic deterioration of the relative wage position of low-paid workers in Russia. The contrast with Poland is quite striking. The relative wage status of a low-paid Russian worker is much worse than that of his Polish counterpart. At the same time, the a toppaid Russian worker earns, in relative terms, much more than his Polish counterpart.

\section{Welfare effects of the increase in wage dispersion: low-paid employment and the working poor}

The increase in wage inequality that has occurred during the transition to some extent has been a natural process, reflecting wages becoming better aligned with productivity differentials among workers. To the extent this has been the case, the increase in wage dispersion has played a positive economic function by rewarding effort and providing better incentives for skill acquisition. At the same time, in some cases the increase in wage inequality might have resulted from non-competitive wage setting practices. On the one hand, firms with monopsony power might have used it to suppress wages of workers, especially those whose bargaining position is weak (e.g. less skilled workers who are easier to replace). On the other, managers might have appropriated rents enjoyed by firms with some monopoly power, and thus award themselves salaries above the competitive level.

Regardless of the causes of the increase in wage inequality, it has important welfare effects. This is particularly the case if the wage distribution widens at the bottom, as it has actually happened during the transition in all transition countries, but especially in the CIS. Low-paid workers have become more numerous and their relative wage position has deteriorated. And low-pay often translates into poverty. After all, a substantial proportion - in some countries the majority- of the poor in transition countries are the "working poor" (World Bank, 2000).

The incidence of low-pay has increased substantially along with the increase in wage inequality. ${ }^{12}$ In many countries the increase has been dramatic. For example, in Latvia and Romania the fraction of low-paid workers increased from virtually zero to 13-14 percent of total (formal sector) employment. In Serbia and Montenegro, the fraction of low-paid workers quadrupled and currently exceeds 20 percent. In Russia the incidence of low-pay has risen from 7 percent before the transition to the current level of 23 percent. In Kyrgyzstan the fraction of low-paid workers has almost tripled, reaching 14 percent. Although in other countries the increase was more modest, it still has been considerable.

In most of the transition economies the incidence of low-pay is presently high by international standards. In European OECD economies the incidence of low-pay is usually well below 10 percent. In contrast in most ECA transition economies the incidence of low-pay much

\footnotetext{
12 We are using here a relative rather than an absolute concept of low-pay. According to the relative approach, low-pay is customarily defined as earnings lower than 50 percent of the median wage. This is a narrow definition which delimits very low wages. A broader definition (not used here) delimits low-pay as earnings less than 66 percent of the median wage.
} 
exceeds 10 percent. Only in the Czech Republic and Hungary the incidence of low-pay is within the EU range (Rutkowski, 2001).

Is the high incidence of low-pay a blessing or a curse? It is usually deemed as a curse, as frequently low-paid workers are poor. However, the high incidence of low-paid jobs can be also viewed as demonstrating the ability of the economy to provide employment to low-productivity workers who otherwise would be unemployed. Hence, to the extent the alternative to low-paid employment is unemployment, the availability of low-paid jobs actually helps to alleviate poverty.

\section{An increase in educational wage premia has been a major factor behind the rise in wage inequality}

The increase in wage dispersion is brought about by widening wage differentials between worker groups (e.g. skill groups) as well as by widening wage differentials within a given group. In other words, rising wage inequality reflects an increase in wage premier to various worker and firm characteristics. These include education and skills, occupation, sector of the economy, industry, or region. There is some evidence that during the transition there has been an increase in wage premia along all of these dimensions. For example, in Poland there is an evidence of the increased wage premia to education, to growing sectors and regions in the economy and to senior occupations (Newell, 2001).

The increase in wage premia to education is probably the most important and the best documented observable factor that has caused the increase in wage dispersion in the transition economies. ${ }^{13}$ Under central planning wage differentials between highly educated workers and less educated workers tended to be relatively small. Evidence for CEE and Russia shows that the situation changed dramatically already during the first few years of the transition (Fleischer et al., 2004). Apparently the demand for high, blue collar skills has sharply risen, and that for less skilled manual labor has fallen. As a result wages and salaries of well educated and highly skilled workers have gone up, while wages of less educated workers have gone down, not only in relative terms but often also in absolute terms. These developments have led to a substantial increase in returns to education, especially to university education. At present, the annualized rate of return to education is similar or higher than that in West European economies (Orazem and Vodopivec, 1994, Vecernik, 1995; Rutkowski, 1996, 2001; Kertesi and Kollo, 2001; Newell and Reilly, 1997; Munich et al., 2000; Sabirianova, 2003).

The increase in the premia to high skills and education (especially university education) has been driven by the private sector. That is, the private sector rewards high educational qualifications better than does the public sector.

More generally, the pace of increase in returns to schooling has been positively related to the speed of market reforms. Returns to education increased faster in countries, where regulatory and institutional constraints on wage-setting were removed earlier. For example, in Ukraine, where the pace of market reforms has been slow, the increase in returns to schooling has been modest and they are still lower than in faster reforming economies of CEE as well as in Russia (Fleischer et al., 2004; Sabirianova Peter and Gorodnichenko, 2004).

\footnotetext{
${ }^{13}$ Evidence comes mainly from CEE, Russia and Ukraine. An earlier study (Newell and Reilly, 1997) found that returns to university education in Uzbekistan in 1995 were significantly lower than in CEE, Russia and in Kazakhstan.
} 


\section{Minimum wages are relatively high in CEE and low in CIS}

Virtually all transition countries have in place minimum wages, although their "bite" measured by the ration of the minimum wage to the average wage differs considerably across country groups. In he European transition economies minimum wages are pitched at a relatively high level, on average around 40 percent of the average wage (Figure 13). The minimum ranges from about one-third of the average wage in Bulgaria and Romania, to over 50 percent of the average wage in Slovakia to two-thirds of the average wage in Slovenia. These minimum wage/average wage ratios are well within the OECD range, although in Europe the ratio is usually higher than in non-EU OECD members.

\section{Figure 13 The "bite" of the minimum wage varies across ECA countries}

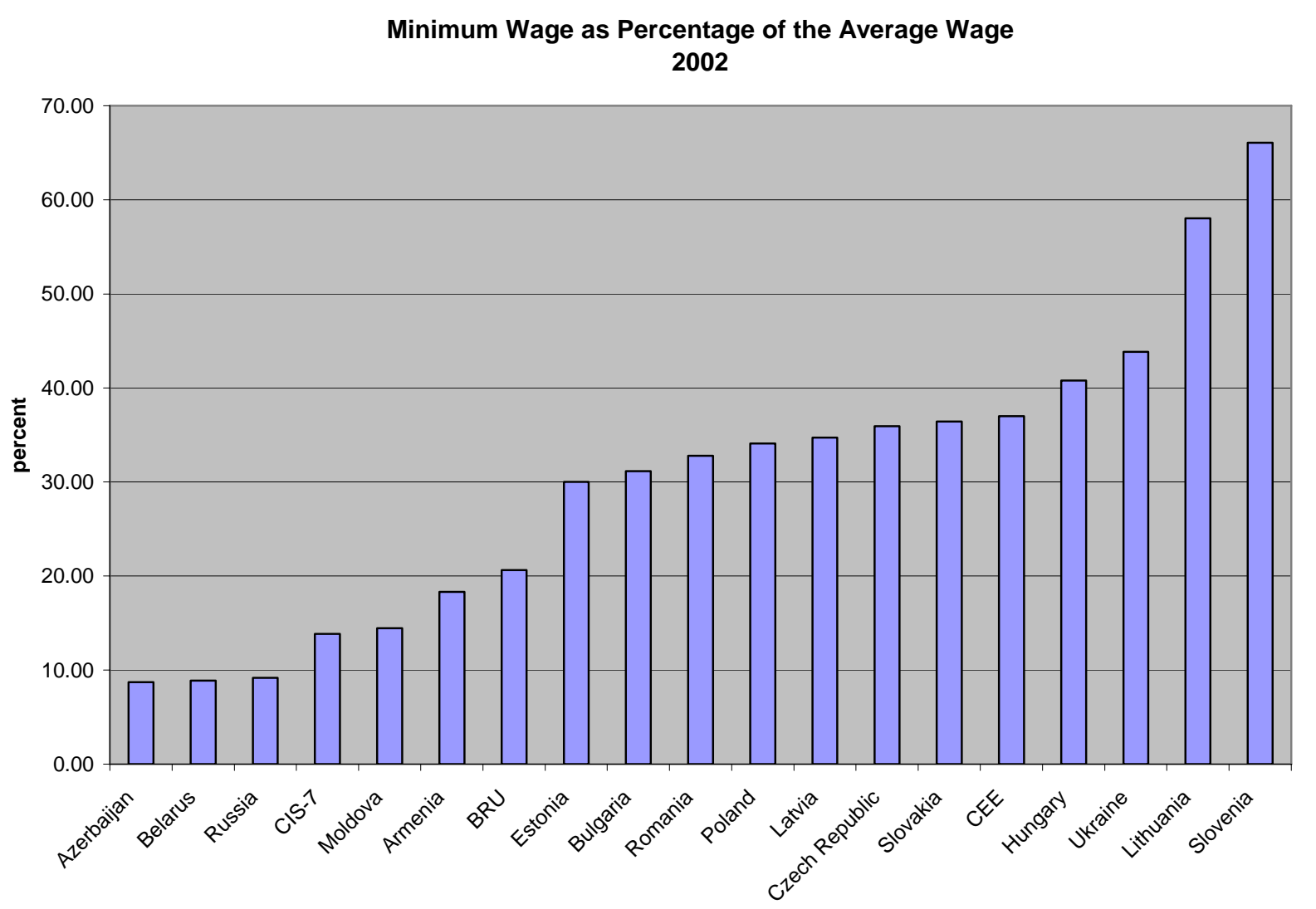

Source: UNICEF TransMONEE database; Bank staff calculations.

In SEE in most cases there is no national minimum wage. However, minimum wages are fixed at the industry level by collective agreements between trade unions and employer representatives. In addition, these countries apply the minimum social security contribution threshold, which tends to be substituted for the minimum wage. ${ }^{14}$

In the CIS national minimum wages are pitched at a much lower proportion of the average wage, with the notable exception of Ukraine, where currently (2002) the minimum wage accounts for 44 percent of the average wage, which is in the upper end of the CEE range.

\footnotetext{
14 The minimum social security contributions threshold is the lowest notional wage which is used as the basis to calculate the amount of social security contributions. In principle workers can received wages that are lower than the threshold, although in practice this seems to be rare.
} 
There has been no clear trend in the minimum wage in CEE and the minimum wage/average wage ratio has been roughly stable over time. However, there has been some variation across countries. For example, in Poland the minimum wage as proportion of the average wage has gradually eroded over time from over 40 to less than 40 percent. In contrast, in Hungary, the minimum wage was recently doubled as the proportion of the average wage (Kertesi and Kollo, 2003).

In the CIS there appear to be an U-shaped trend of the evolution of the minimum wage. Minimum wages tended to be set at a relatively high level at the outset to the transition. However soon they lost any practical meaning along with the emergence of the practice of nonpayment of wage and wage arrears. In the mid 1990s minimum wages in most of the CIS countries accounted for less than 10 percent of the average wage, which by all likelihood implied that they effectively lost their function of the wage floor and were non-binding. In early 2000s some CIS countries have started to reverse this trend and have attempted to restore the minimum wage in its role of policy instrument. For example, in Ukraine the minimum wage declined from 24 percent of the average wage in 1990 to 1 percent (which implies that it lost any practical meaning) but then was raised to 44 percent in 2002, which implies that it regained its role as the tool of limiting wage inequalities and protecting wages of workers with weak bargaining power. A similar rebound of the minimum wage, although much less pronounced, has occurred in Armenia, and to a still lesser extent in Moldova.

\section{Minimum wage effects: wage distribution, employment and poverty}

Rigorous analysis necessary to determine welfare effects of minimum wages in ECA is absent. ${ }^{15}$ So, we limit ourselves to formulating some tentative hypotheses and presenting whatever circumstantial evidence that is available.

Do minimum wages in ECA affect the wage distribution? It seems that higher minimum wages limit wage dispersion, which is what one would expected. Wage inequalities tend to be much higher in the CIS countries, where the minimum wages are so low (relative to the average wage), that are unlikely to be binding, than in the European transition economies, where minimum wages are substantially higher and thus likely to be binding.

Do the minimum wages have a negative employment effect? Obviously not if they are nonbinding as in most of the CIS. However, if the minimum wage is raised so as it becomes binding the negative employment effect becomes likely to be significant. For example, in Hungary the government increased the minimum wage by 57 percent in 2001 so as it currently accounts for about 40 percent of the average wage. There is evidence that this hike reduced employment in the small firm sector; and adversely affected the job retention and job finding probabilities of low-wage workers. ${ }^{16}$ The depressed regions were more severely affected, thus spatial inequalities were amplified rather than reduced (Kertesi and Kollo, 2003).

More circumstantial evidence on minimum wage effects comes from the examination of the wage distribution for groups that are likely to be affected. For example, in Poland in the late 1990 s the minimum wage accounted for about 40 percent of the national average wage. However, it accounted for 65 percent of the average wage for young workers, 72 percent for workers in elementary occupations and as much as 82 percent for bottom-quintile workers. These figures suggest that the minimum wage truncates the wage distribution for less-productive workers and thus is likely to price them out of employment (Rutkowski and Przybyla, 2002).

15 A notable exception is the paper by Kertesi and Kollo (2004).

16 The small firm sector lost about $3 \%$ of its jobs in less than a year. 
Do higher minimum wages help to alleviate poverty in ECA? The answer seems negative. There is substantial international evidence, that minimum wages are not an effective anti-poverty instrument (OECD, 1998). The main reason is that they are not well-targeted: most of the lowpaid workers are not poor, as poverty is concentrated among jobless families. Limited evidence from ECA countries is consistent with this general pattern. In Poland the bulk (around threequarters) of low-paid workers is not poor. This reflects the fact that only a minority (about one in four) low-paid workers are household heads. Instead most are secondary earners, complementing family income. As a result, low paid workers only a tiny fraction of the poor (including working age poor). Under such circumstances an increase in the minimum wage is unlikely to translate into a discernible decline in poverty rates, all the more so that the wage hike is likely to come at the price of some employment loss

\section{SUMMARY OF MAIN FINDINGS}

This paper presented an overview of labor market developments in transition economies of Europe and Central Asia from the early 1990s until the early 2000s. The paper's main findings can be summarized as follows.

- Transition has lead to a large fall in the number of jobs and accompanying underutilization of labor, negatively affecting social welfare and growth prospects in ECA. However, the adjustment to the transition shock has taken different forms in ECA sub-regions. In the European transition economies the job fall has translated into open unemployment. Within this group there differences in labor market conditions associated with the pace of enterprise restructuring and the rate of job creation. In the CIS the fall in labor demand has led largely to underemployment (hidden unemployment). Many workers hold low-productivity jobs in unrestructured and unprofitable enterprises, in the informal sector, and in subsistence agriculture, which is the employer of last resort.

- Limited job opportunities have also led to discouragement and massive labor force withdrawal, especially among younger and older cohorts as well as women. The combined effect of unemployment and labor force withdrawal was a substantial fall in the employment to population ratio. This fall was stronger in European transition economies than in the CIS countries.

- The low open unemployment and high employment/population ratio that prevail in many CIS countries hide significant problems in their labor markets. They often point to delayed enterprise restructuring with persistent over-staffing and - especially in the lowincome CIS - to the dominance of low productivity jobs in the informal sector as a means of earning subsistence income. The latter feature is typical of developing countries, where social protection is lacking and thus for most workers unemployment is not an affordable option.

- Coping strategies of displaced workers differed between the European and the CIS transition economies, too. In European transition economies many displaced and discouraged workers have taken advantage of relatively generous non-work benefits (early retirement and disability pensions, unemployment benefits and social assistance). In most CIS countries, these benefits are less diffused and many laid-off workers have moved to subsistence agriculture, self-employment, and casual work in the informal sector.

- While the emergence of unemployment in the wake of the transition was expected, its persistence is a source of major concern. In particular, outflows from unemployment to 
jobs have been low in many cases leading to build up of a large pool of long-term unemployed, with a negative effect on their employment prospects.

- Real wages have fallen sharply during the early phase of the transition but have rebounded since the mid 1990s following the resumption of economic growth. The fall in wages was much more pronounced in the CIS economies (where enterprises restructured slowly and were reluctant to lay-off workers) than in the European transition economies (where enterprises restructured by shedding off redundant labor). The uniform wage growth during the second stage of the transition (when economic growth resumed) coupled with limited, if any, employment growth implies that output and associated productivity growth are translated into higher wages rather than higher employment.

- Wage inequalities have increased substantially across ECA. The increase has been however more moderate in European than in CIS transition economies. As a result, the current level of earnings inequality is still relatively modest in CEE and SEE while it is very high by international standards in most CIS countries. One important driving force behind the growth in wage inequalities has been the increase in returns to education and high (white collar) skills. However, wage inequalities also reflect firm specific characteristics, such as profitability, ownership, industry affiliation, etc.

- The segmentation of the labor markets has been an important feature of the transition in ECA countries. While the informal sector has become sizeable in European transition economies (by European standards), it often accounts for the bulk of the private sector in some low-income CIS countries, which resemble in this respect developing countries. In European transition economies the informal sector is mainly driven by tax evasion as well as by the avoidance of strict regulations. In contrast, in the CIS countries the informal sector is largely the employer of last resort. The informal sector there is concentrated in agriculture while in the European transition economies it is concentrated in the expanding services sector. The growth of the informal sector is associated with the increased incidence of casual jobs as well as with self-employment.

- Regional disparities in labor market conditions across ECA are large and persistent. They are particularly pronounced in Russia, which is a huge and heterogeneous country, but they are large also in European transition economies, where the unemployment rate in high unemployment regions is two to three times as high as in low unemployment regions. Job creation and employment prospects are heavily concentrated around large urban agglomerations with diversified economic structure and in particular with an expanding service sector. These growth poles are surrounded by economically depressed regions, often one-company towns, where job opportunities are scarce and unemployment is high. Equilibrating forces are too weak to alleviate the imbalances. Labor mobility in ECA is relatively low, inter alia due to an underdeveloped housing market. Although regional wages tend to respond to regional unemployment this is not enough to entice entry of new firms and investment which are a prerequisite for job creation.

- Labor market transition has created both losers, and winners. The losers include less skilled blue collar workers in declining industries and regions, among whom unemployment is high and wages are low, and falling in relative terms. The winners comprise well educated white collar workers who find employment mainly in the expanding services sector and who command high wages. 
- There are signs of an emerging divide between labor markets in transition economies of Europe and those of Central Asia. Labor markets in the European transition economies in many respects resemble those in developed economies of Europe, in both positive (e.g. productivity growth) and negative aspects (e.g. high and stagnant unemployment). In contrast, labor markets in the low-income CIS seem to become similar to those in other low-income countries, with typical characteristics such as the dominant informal sector, underemployment and low-productivity employment. Table 9 summarizes the main differences between labor markets in the European and the CIS transition economies.

Table 9 Labor markets differ between the European and the CIS economies in a number of important dimensions.

\begin{tabular}{|c|c|c|}
\hline Labor market characteristics & $\begin{array}{l}\text { Middle-income European } \\
\text { transition economies }\end{array}$ & $\begin{array}{c}\text { Low-income CIS transition } \\
\text { economies }\end{array}$ \\
\hline Main labor market issue & Unemployment & underemployment \\
\hline Adjustment to transition shock & $\begin{array}{l}\text { quantity (employment);labor } \\
\text { moving to expanding services } \\
\text { sector }\end{array}$ & $\begin{array}{c}\text { price (wages); labor shifting } \\
\text { back to subsistence } \\
\text { agriculture }\end{array}$ \\
\hline Investment climate & generally favorable & less favorable \\
\hline $\begin{array}{l}\text { Market oriented reforms and } \\
\text { enterprise restructuring }\end{array}$ & Advanced & less advanced \\
\hline $\begin{array}{l}\text { Employment protection } \\
\text { legislation }\end{array}$ & relatively liberal & strict \\
\hline $\begin{array}{l}\text { Enforcement of labor market } \\
\text { regulations }\end{array}$ & relatively strong & weak \\
\hline Unemployment insurance system & Developed & largely ineffective \\
\hline Economic structure & $\begin{array}{c}\text { dominance of services and } \\
\text { industry }\end{array}$ & dominance of agriculture \\
\hline Informal sector & $\begin{array}{c}\text { marginal, driven by tax } \\
\text { evasion and avoidance of } \\
\text { regulations }\end{array}$ & $\begin{array}{l}\text { large, driven by lack of job } \\
\text { opportunities in the formal } \\
\text { sector }\end{array}$ \\
\hline Labor force location & largely urban & largely rural \\
\hline Labor force skills & High & low \\
\hline Productivity (wages) & High & low \\
\hline Earnings inequality & Modest & high \\
\hline
\end{tabular}




\section{REFERENCES}

Atkinson, Anthony B. and Micklewright John (1992), Economic Transformation in Eastern Europe and the Distribution of Income, Cambridge, UK: Cambridge University Press.

Boeri, Tito (1995), "Unemployment Dynamics and Labor Market Policies", in S. Commander and F. Coricelli (eds.), Unemployment Restructuring, and the Labor Market in Eastern Europe and Russia, World Bank, Washington, D.C.

Boeri, Tito and Katherine Terrell (2002), Institutional Determinants of Labor Reallocation in Transition, Journal of Economic Perspectives, Vol. 16, No. 1. (Winter)

Boeri, Tito and Stefano Scarpetta (1996), "Regional mismatch and the transition to a market economy”, Labour Economics 3, pp. 233-254.

Bornhorst, Fabian and Simon Commander (2004), "Regional Unemployment and its Persistence in Transition Countries", IZA Discussion Paper No. 1074, Bonn.

Commander Simon and Janos Kollo (2004), The Changing Demand for Skills: Evidence from the Transition, IZA

Earle, John and Zuzana Sakova (2000), "Business Start-Ups or Disguised Unemployment? Evidence on the Character of Self-Employment From Transition Economies", Labour Economics, 7(5), 575-601.

Huber, Peter (2003a), Intra-national Labour Market Adjustment in the Candidate Countries, Austrian Institute for Economic Research (WIFO), processed.

Huber, Peter (2003b), Quantity Adjustments in Candidate Countries Regional Labour Markets, Austrian Institute for Economic Research (WIFO), processed.

Fidrmuc, Jan (2003), "Migration And Regional Adjustment To Asymmetric Shocks In Transition Economies”, CEPR Discussion Paper No. 3798.

Fleisher, Belton, Klara Sabirianova and Xiaojun Wang (2004), "Returns to Skills and the Speed of Reforms: Evidence from Central and Eastern Europe, China and Russia", IZA Discussion Paper No. 1182.

Kertesi, Gábor and János Köllő (2001), "Economic transformation and the revaluation of human capital - Hungary, 1986-1999”, Budapest Working Papers On The Labour Market, No. 2001/4

Kertesi, Gábor and János Köllő (2003), Fighting "Low Equilibria” by Doubling the Minimum Wage ? Hungary's Experiment, IZA Discussion Paper No. 970.

Kolev, Alexandre and Catherine Saget (2003), Towards a Better Understanding of the Nature, Causes and Consequences of Youth Labor Market Disadvantage: Evidence from South-East Europe, A background paper for a World Bank regional report on Youth Empowerment and Social Inclusion in South-East Europe, processed.

Munich, Daniel, Jan Svejnar and Katherine Terrel (2000), "Returns to Human Capital under the Communist Wage Grid and During the Transition to a Market Economy", IZA Discussion Paper No. 1182.

Newell, Andrew (2000), "Regional Unemployment and Industrial Restructuring in Poland”, IZA Discussion Paper No. 194

Newell, Andrew (2001), "The Distribution of Wages in Transition Countries", IZA Discussion Paper No. 267, Bonn. 
Newell, Andrew and Barry Reilly (1997), Rates of Returns to Educational Qualification in the Transitional Economies, UNICEF, Florence, processed.

OECD (1998), Employment Outlook, Paris.

Orazem, Peter F. and Milan Vodopivec (1995), "Winners and Losers in Transition: Returns to Education, Experience and Gender in Slovenia", World Bank Economic Review, 9, 2, 201-230.

Paci, Pierella (2002), Gender in Transition, World Bank, Washington, DC.

Rashid, Mansoora and Jan Rutkowski (2001), Labor Markets in Transition Economies: Recent Developments and Future Challenges, Social Protection Discussion Paper No. 0111, World Bank, Washington, D.C.

Riboud, Michelle, Carolina Sanchez-Paramo, and Carlos Silva-Jauregui (2002), "Does Eurosclerosis Matter? Institutional Reform and Labor Market Performance in Central and Eastern European Countries," in B. Funck and L. Pizzati (eds.), Labor, Employment, and Social Policies in the EU Enlargement Process, World Bank, Washington, D.C.

Rutkowski, Jan (1996), "High Skills Pay-off: the Changing Wage Structure during Economic Transition in Poland", Economics of Transition, 4(1), 89-112.

Rutkowski, Jan (1999), "Labor Markets and Poverty in Bulgaria”, Social Protection Discussion Paper NO. 9918, World Bank, Washington, D.C.

Rutkowski, Jan (2001a), "Earnings Inequality in Transition Economies of Central Europe. Trends and Patterns During the 1990s", Social Protection Discussion Paper No. 0117, World Bank, Washington, D.C.

Rutkowski, Jan (2003a), "Rapid Labor Reallocation with a Stagnant Unemployment Pool: The Puzzle of the Labor Market in Lithuania", Policy Research Working Paper No. 2946, World Bank, Washington, DC.

Rutkowski, Jan (2003b), Why is Unemployment so High in Bulgaria?, Policy Research Working Paper No. 3017, World Bank, Washington, DC.

Rutkowski, Jan (2003c), "Does Strict Employment Protection Discourage Job Creation? Evidence from Croatia", Policy Research Working Paper No. 3104, World Bank, Washington, DC.

Rutkowski, Jan (2004), Firms, Jobs and Employment in Moldova, Policy Research Working Paper No. 3253, World Bank, Washington, DC.

Rutkowski, Jan and Marcin Przybyla (2002), "Poland. Regional Dimensions of Unemployment", in: in B. Funck and L. Pizzati (eds.), Labor, Employment, and Social Policies in the EU Enlargement Process, World Bank, Washington, D.C.

Sabirianova Peter, Klara (2003), "Skill-Biased Transition: The Role of Markets, Institutions, and Technological Change”, William Davidson Institute Working Paper Number 616, Michigan.

Sabirianova Peter, Klara and Yuriy Gorodnichenko (2004), Returns to Schooling in Russia and Ukraine: A Semiparametric Approach to Cross-Country Comparative Analysis, William Davidson Institute Working Paper Number 719.

Scarpetta, Stefano (1995), "Spatial Variations in Unemployment in Central and Eastern Europe: Underlying Reasons and Labour Market Policy Options”, in: Stefano Scarpetta and Andreas Wörgötter Eds. The Regional Dimension of Unemployment in transition Economies, OECD, Paris. 
Scarpetta, Stefano and Peter Huber (1995), "Regional Economic Structures and Unemployment in Central and Eastern Europe: An Attempt to Identify Common Patterns", in: Stefano Scarpetta and Andreas Wörgötter Eds. The Regional Dimension of Unemployment in transition Economies, OECD, Paris.

Schneider, Friedrich (2002), The Size and Development of the Shadow Economies of 22 Transition and 21 OECD Countries, IZA DP No. 514.

Schneider, Friedrich and Robert Klinglmair (2004), Shadow Economies Around the World, IZA DP No. 1043.

Svejnar, Jan (1999) Labour Market in the Transitional Central and East European Economies, in Ashenfelter, Orley and David Card, Handbook of Labour economics, Volume 3, Elsevier Science. pp. $2810-2857$

Vecernik, Jiri (1995), "Changing earnings distribution in the Czech Republic: Survey Evidence from 1988-1994”, Economics of Transition, 3(3), 355-371.

Verme, Paolo (2004),

World Bank (1998), Enhancing Growth, FYR Macedonia Country Economic Memorandum, World Bank, Washington, DC.

World Bank (1999), Focusing on the Poor, FYR of Macedonia, World Bank, Washington, D.C.

World Bank (2000), Making Transition Work for Everyone, World Bank, Washington, DC.

World Bank (2001), Poland Labor Market Study - The Challenge of Job Creation, Washington, D.C.

World Bank (2002b) Labor Market in the Postwar Bosnia and Herzegovina: How to Encourage Businesses to Create Jobs and Increase Worker Mobility, Washington, D.C.

World Bank (2003a), The Russian Labor Market: Moving from Crisis to Recovery, Washington, D.C.

World Bank (2003b), A Study Of Informal Labor Market Activity In The Cis-7, Washington, D.C.

World Bank (2003c), Tackling Unemployment. FYR Macedonia Country Economic Memorandum, World Bank, Washington, D.C. 
Table A1 Regional difference in labor market conditions: unemployment and employment

\begin{tabular}{|c|c|c|c|}
\hline & & Unemployment rate & Employment rate \\
\hline \multirow[t]{6}{*}{ Bulgaria } & Severozapaden & 32.1 & 42.0 \\
\hline & Severen Tsentralen & 21.1 & 49.6 \\
\hline & Severoiztochen & 23.5 & 49.4 \\
\hline & Yugozapaden & 16.2 & 55.5 \\
\hline & Yuzhen Tsentralen & 19.2 & 51.1 \\
\hline & Yugoiztochen & 26.7 & 45.9 \\
\hline \multirow[t]{8}{*}{ Czech Republic } & Praha & 6.5 & 72.0 \\
\hline & Strední Cechy & 7.5 & 66.6 \\
\hline & Jihozápad & 5.8 & 68.2 \\
\hline & Severozápad & 12.5 & 62.6 \\
\hline & Severovýchod & 7.1 & 66.4 \\
\hline & Jihovýchod & 8.3 & 64.8 \\
\hline & Strední Morava & 9.9 & 62.5 \\
\hline & Moravskoslezko & 15.8 & 57.8 \\
\hline \multirow[t]{7}{*}{ Hungary } & Közép-Magyarország & 5.0 & 60.6 \\
\hline & Közép-Dunántúl & 4.1 & 60.1 \\
\hline & Nyugat-Dunántúl & 4.3 & 62.8 \\
\hline & Dél-Dunántúl & 8.0 & 52.7 \\
\hline & Észak-Magyarország & 8.4 & 49.6 \\
\hline & Észak-Alföld & 8.7 & 49.2 \\
\hline & Dél-Alföld & 5.9 & 56.1 \\
\hline \multirow[t]{16}{*}{ Poland } & Dolnoslaskie & 25.0 & 48.3 \\
\hline & Kujawsko-Pomorskie & 23.0 & 52.0 \\
\hline & Lubelskie & 18.9 & 57.7 \\
\hline & Lubuskie & 24.7 & 50.0 \\
\hline & Lódzkie & 21.3 & 53.7 \\
\hline & Malopolskie & 15.9 & 60.0 \\
\hline & Mazowieckie & 16.9 & 59.2 \\
\hline & Opolskie & 21.5 & 53.2 \\
\hline & Podkarpackie & 22.3 & 55.3 \\
\hline & Podlaskie & 20.8 & 58.3 \\
\hline & Pomorskie & 19.1 & 53.4 \\
\hline & Slaskie & 21.5 & 48.5 \\
\hline & Swietokrzyskie & 22.1 & 49.9 \\
\hline & Warminsko-Mazurskie & 23.1 & 49.2 \\
\hline & Wielkopolskie & 20.2 & 54.0 \\
\hline & Zachodniopomorskie & 22.3 & 50.7 \\
\hline \multirow[t]{8}{*}{ Romania } & Nord-Est & 19.7 & 66.9 \\
\hline & Sud-Est & 16.2 & 58.9 \\
\hline & Sud & 19.0 & 65.5 \\
\hline & Sud-Vest & 19.6 & 70.4 \\
\hline & Vest & 12.1 & 61.9 \\
\hline & Nord-Vest & 15.4 & 63.4 \\
\hline & Centru & 12.4 & 62.2 \\
\hline & Bucuresti & 10.8 & 55.5 \\
\hline \multirow[t]{4}{*}{ Slovak Republic } & Bratislavský & 8.5 & 69.5 \\
\hline & Západné Slovensko & 18.7 & 57.2 \\
\hline & Stredné Slovensko & 21.3 & 55.2 \\
\hline & Východné Slovensko & 24.5 & 52.1 \\
\hline
\end{tabular}

Source: Eurostat 